\title{
Türkiye'de Deprem Performansına Dayalı Bina Kimlik Bilgilerinin Oluşturulmasına Yönelik Çalışma ve Öneriler
}

\author{
Merşa ARAL ${ }^{1}$, Gökhan TUNÇ²
}

\section{Özet}

Türkiye tektonik konumu itibariyle yıkıcı etkileri olan büyük magnitüdlü depremleri üretebilen fay hatlarına sahip aktif bir deprem kușağı üzerinde yer almaktadır. Bu konumu itibarı ile ülke her an deprem tehlikesiyle karşı karşıyadır. Depremlerin yer ve zaman ile ilgili özelliklerinin tahmin edilemez oluşu, insanların bu tür bir doğal afete konutlarında veya çalışma ortamında yakalanma ihtimallerini de yüksek riskli hale getirmektedir. Bu yüzden zaman geçirilen mekânı temsil eden binaların ve yapıların deprem sırasında veya sonrasındaki performansları önemli bir değerlendirme kriteri haline gelmektedir. Bu çalışmada, konutlar özelinde gerekli inceleme ve değerlendirmeler yapılarak kullanıcının (tüketicinin) mekânın yapısal sağlamlığına yönelik endișeleri ve beklentileri ele alınacaktır. Dolayısı ile yaşam alanını tarifleyen binaların teknik özellikleri ile depreme dayanıklılık durumuna ait bilgilerin tüketiciye nasıl ulaşacağı bu çalışmanın özünü teşkil edecektir. Bu kapsam dâhilinde binalar için kimlik bilgisi oluşturulmasına yönelik altyapı çalışması hakkında detaylı bilgiler verilecek, gerekli görüş ve önerilerde bulunulacaktır. Bu öneriler doğrultusunda bilinçli tüketici kitlesinin oluşumu hedeflenerek depremin yaratabileceği yıkıcı etkiler ve can kaybının en az düzeyde gerçekleşmesi sağlanmış olacaktır.

Anahtar Kelimeler: Bina Kimliği, Bilinçli Tüketici, Deprem Kimliği, Deprem Performansı, Afet Yönetimi

\section{A Proposal for the Establishment of Building Identity Numbers in Turkey Based on the Performance of Buildings During Earthquakes}

\begin{abstract}
Turkey lies on an active seismic belt with very severe earthquake fault lines that can produce devastating effects. Thus, the country is always in danger of an earthquake. Moreover, due to the unpredictability of the location and time characteristics of earthquakes, there is always a high risk that residences and work environments will be severely damaged. Therefore, the performance of buildings and structures during and after an earthquake is an important evaluation criterion. In this study, the concerns and expectations of users (consumers) concerning the structural strength of their living and working spaces will be examined and evaluated. The technical features of the buildings that define their living and working spaces, and how information regarding their

\footnotetext{
${ }^{1}$ Gazi Üniversitesi, İnşaat Mühendisliği Bölümü, Ankara e-posta/e-mail: aral.mersa@gmail.com ORCID No: 0000-0001-6772-4132

2 Atılım Üniversitesi, Dr. Öğretim Üyesi, İnşaat Mühendisliği Bölümü, Ankara

İlgili yazar e-posta/ Corresponding author e-mail: gokhan.tunc@atilim.edu.tr ORCID No: 0000-0002-8307-1060
}

Bu makaleye atıf yapmak için- To cite this article Aral, M., ve Tunç, G. (2021). Türkiye'de Deprem Performansına Dayalı Bina Kimlik Bilgilerinin Oluşturulmasına Yönelik Çalıșma ve Öneriler. Afet ve Risk Dergisi, 4(1), 20-41. 
earthquake resistance reaches users, will constitute the essence of this study. Detailed information about the infrastructure needed to create building identification numbers will be provided, and suggestions will be made with respect to the Turkish context. Creating a conscious consumer base and minimizing the destructive effects and loss of life caused by earthquakes are among the aims of these recommendations.

Keywords: Building ID Number, Conscious Consumer, Earthquake Identity Number, Earthquake Performance, Disaster Management

\section{GíRiş}

İnsanların kontrolü dışında meydana gelen can ve mal kayıplarına sebep olan olaylar doğal afet olarak tanımlanmaktadır. Doğal afetlerin meydana gelmesinde belirli bir zaman kavramı olmadığı için günümüz teknolojisi ile afetlerin ne zaman ve ne şekilde gerçekleşeceğinin tahmin edilebilmesi de oldukça zordur. İnsanlar tarih boyunca jeolojik, klimatik, biyolojik ve sosyal afetlere tanıklık etmiştir. Türkiye'de de geçmişten günümüze depremler, heyelanlar, erozyon, su baskınları, kaya ve çı̆̆ düşmeleri gibi doğal afetler meydana gelmektedir. Etkileri açısından bu afetler incelendiğinde \%61 ile deprem doğal afetlerin en başında gelmektedir (Türk Mühendis ve Mimar Odaları Birliği, TMMOB, 2012). Depremin önceden bilinememesi, durdurulamaması ve aniden olması gibi özellikleri depremi diğer doğal afetlerden çok daha farklı kılmaktadır. Türkiye'nin deprem tehlike haritası incelendiğinde ülke topraklarının \% 96'sının deprem tehlikesine sahip bölgelerde olduğu ve nüfusun \% 98'inin ise bu bölgelerde yaşamını sürdürdüğü görülmektedir (Özmen ve Can, 2010). Bu risk göz önüne alındığında olasılıksal sismik tehlike hesap yöntemi kullanılarak çeşitli gerçekleșme olasılıkları ve yer hareketi parametreleri için yeni Türkiye Deprem Tehlike Haritasının (TDTH) çıkarılmış olması önem arz etmektedir. TDTH için yatay yönde yer sarsıntısı tehlike değerleri dört farklı tekrarlanma aralıkları ve olasılıklarına (her $43,75,475$ ve 2475 yılda bir tekerrür etmesi ya da sırası ile 50 yılda aşılma olasılığı $\% 68, \% 50$, $\% 10$ ve $\% 2$ olması durumu) göre hesaplanmıștır. Binaların deprem tasarımlarında bu bilgilerin kullanılıyor olması, 2018 yılından sonrası için inşa edilenlerin göçme ihtimalini önceki yıllarda yapılanlara göre çok daha az riskli hale getirmektedir.

Özellikle günümüzde meydana gelen depremlerde oluşan can ve mal kayıpları mevcut bina stoklarının ve yeni inşa edilecek binaların depreme dayanıklılık bilgilerinin sorgulanmasına neden olmuştur. Durum böyleyken mevcut binaların depreme dayanıklılık durumları, olması muhtemel depremlerde hangi binaların hasar alacağı ile ilgili incelemeler ülkemizin belirli bölgelerinde yapılmış olsa da tüketiciler (kullanıcılar) bu bilgilere ya doğrudan ulaşamamakta ya da teknik detaylardan dolayı anlaşılır bulmamaktadır (Uzun ve Balyemez, 2020; Sabah ve Bayraktar, 2020; Süer Toybıyık, 2017). Bu zorluklara rağmen tüketiciler, oturdukları ya da alacakları binaların teknik özelliklerini ve depreme dayanıklılık bilgisini öğrenmenin kendileri için önemli olduğu görüşündedir. Fakat mevcut sistemde tüketiciye doğrudan verilecek bir bilgi envanterinin henüz hazır olmaması, bu talebin karşılanmasındaki en önemli engel olarak karşımıza çıkmaktadır.

$\mathrm{Bu}$ çalışmada yaşam alanını tarifleyen binaların depreme dayanıklılık durumu ile teknik ve fiziki özelliklerinin tüketiciye nasıl ulaștırılacağına yönelik metotlar Türkiye özelinde ele alınacaktır. Bu kapsamda deprem tanımı yapılarak, aktif fay hatlarından bahsedilecek, fay hatları üzerinde meydana gelen son yıkıcı depremler belirtilerek bu depremlerin Türkiye üzerindeki etkileri ele alınacaktır. Ayrıca makalede, bilinçli tüketici kitlesinin nasıl oluşturulması gerektiğine yönelik çözüm önerilerine yer verilerek, çalışmanın özünü oluşturan binalar için kimlik bilgisi hazırlanmasında ihtiyaç duyulan altyapı çalışması hakkında detaylı bilgiler sunulacaktır. 
Türkiye'de Deprem Performansına Dayalı Bina Kimlik Bilgilerinin Oluşturulmasına Yönelik Çalıșma ve Öneriler

\section{DEPREM}

Yer kabuğu içindeki kırılmalardan dolayı ani olarak ortaya çıkan titreşimlerin dalgalar halinde yayılarak geçtikleri ortamları sarsmasına deprem denir (Afet ve Acil Durum Yönetimi Bașkanlığı, AFAD, 2019). Depremler, tektonik ve volkanik depremler olmak üzere ikiye ayrılır. Yer kabuğu içindeki levhaların hareketi sonucu meydana gelen depremler, tektonik deprem olarak nitelendirilir. Dünyada meydana gelen depremlerin \%90'ı tektonik deprem sınıfına girer (İşçi, 2008). Türkiye'de meydana gelen depremlerin tamamı ise tektonik türden depremlerdir. Diğer bir deprem türü ise volkanik püskürme sonucu oluşan volkanik depremlerdir. Türkiye'de aktif bir yanardağ olmadığı için bu deprem türüne ülkemizde rastlanmamaktadır (Afyon Kocatepe Üniversitesi Deprem Uygulama ve Araştırma Merkezi, 2020).

Türkiye, coğrafi yapısı itibariyle yıkıcı etkileri olan ve büyük magnitüdlü depremler üretebilen fay hatlarına sahip Alp-Himalaya deprem kuşağı üzerinde yer almaktadır. Türkiye diri fay haritasına göre ülkemizdeki Kuzey Anadolu Fay hattı (KAF) ile Doğu Anadolu Fay hattı (DAF) büyük magnitüdlü depremler üreten fay hatlarıdır (Şekil 1). Ayrıca Doğu ve Güney Doğu Anadolu'daki Bitlis Bindirme Zonu (BBZ) ile Trakya'nın kuzey bölgesi hariç Marmara ve Ege bölgeleri de ülkemizdeki deprem riski en yüksek bölgeler olarak karşımıza çıkmaktadır (Maden Tetkik ve Arama Genel Müdürlüğü, MTA, 2020a).

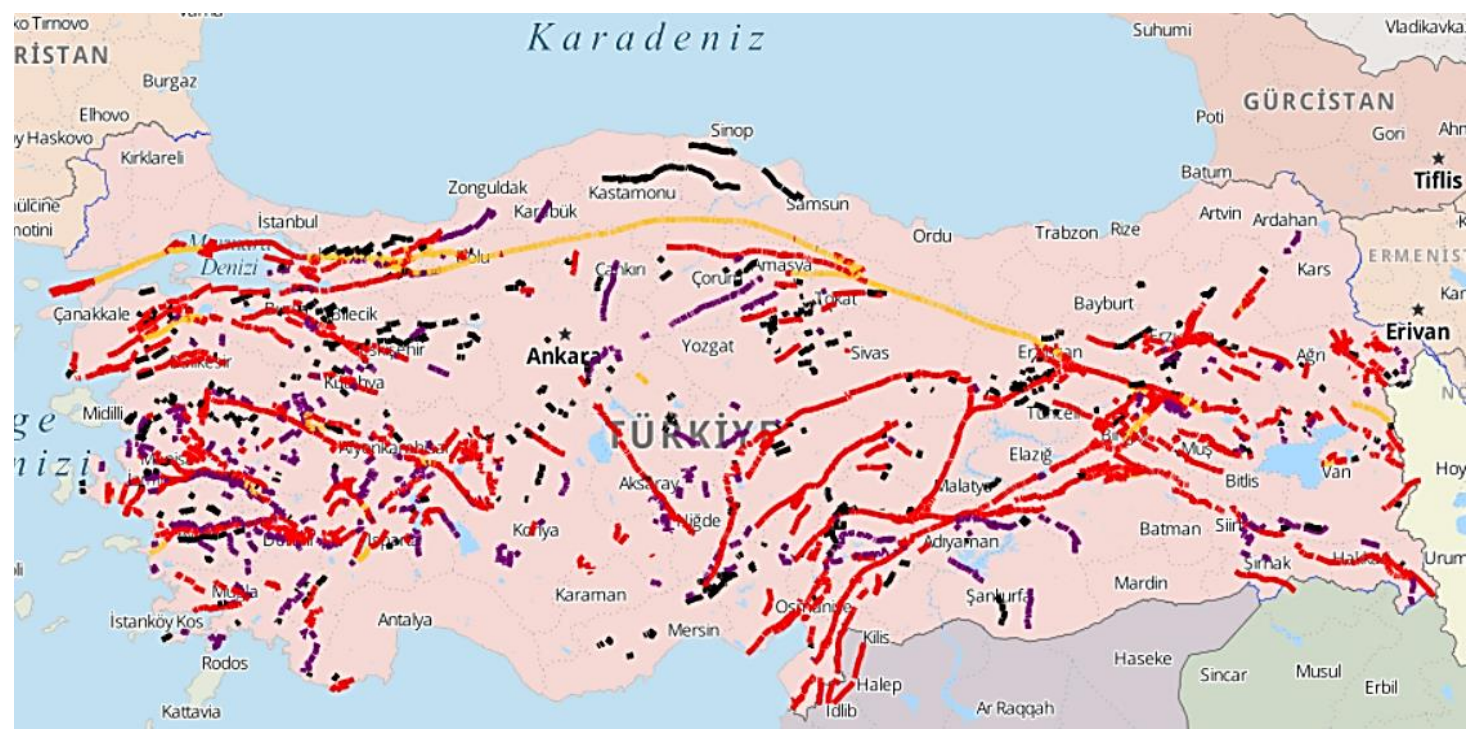

Şekil 1. Ülkemizdeki aktif fay hatları (MTA, 2020b)

\section{1. Önemli Depremler ve Türkiye Üzerindeki Etkileri}

Deprem bölgesinde yer alan ülkemizde 1999 ila 2020 yılları arasında lokal magnitüdleri (ML, yerel büyüklük) 5.0 ve üzeri olan toplam 158 deprem meydana gelmiştir (AFAD, 2020). Așağıdaki tabloda, can ve mal kaybına yol açan lokal magnitüdleri (ML) 5.0 ve üzeri olan depremlere ait bilgiler yer almaktadır (bakınız Tablo 1).

Tablo 1'de verilen depremler yol açtığı sonuçlara göre incelendiğinde ortak nokta olarak en olumsuz paydayı can ve mal kayıplarıyla birlikte yaralanmaların oluşturduğu görülmektedir. Tablodaki verilere göre, 2000 yılından 2020 yılına kadar büyük kayıpların yaşandığı 5 önemli deprem yer almaktadır. Bu 5 önemli depremin 2 tanesi 2020 yılında yaşamış olduğumuz ElazığSivrice ile Seferihisar-İzmir açıklarında meydana gelen Ege Denizi depremleridir. Sivrice depreminde 44 kiși yașamını yitirmiş, 1607 kiși yaralanmıș, 633 bina yıkılmış ve 10.762 bina da ağır hasar tespit edilmiştir (AFAD, 2020; Mertol, Tunç ve Akış, 2020). Ege Denizi depremine ait 
güncel veriler ise makale hazırlık aşamasında meydana geldiği için bu çalışmaya dâhil edilmemiştir.

Tablo 1. 1980-2020 yılları arasında meydana gelen ve lokal magnitüdleri (ML) 5.0 ve üzeri olan bazı depremlere ait bilgiler

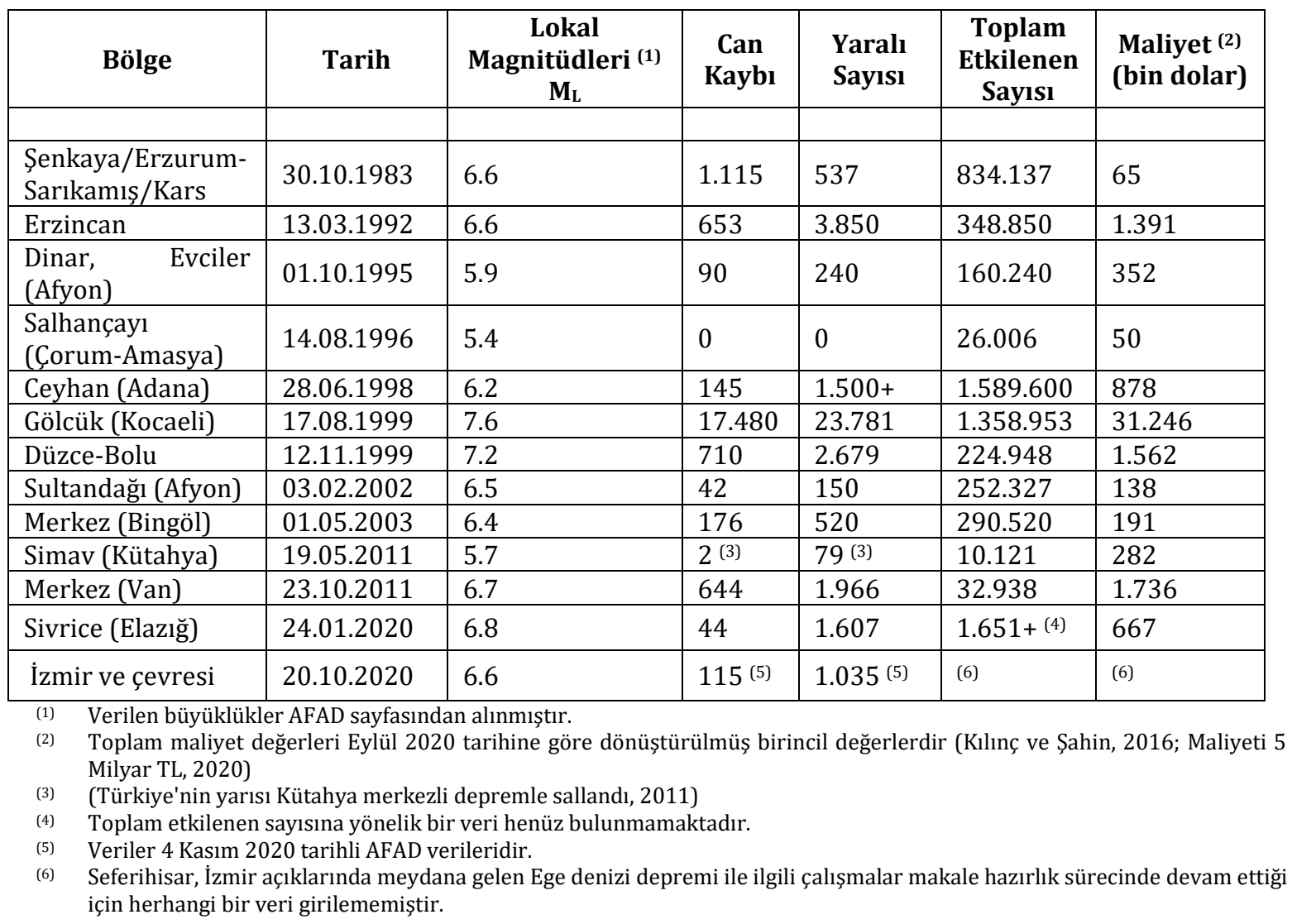

Şu ana kadar meydana gelen depremleri incelediğimizde hem fiziki kayıpların yaşandığını hem de ekonomik, sosyal ve psikolojik etkilerin oluştuğunu görmekteyiz. Depremlerin ekonomik etkileri, birincil (doğrudan) ve ikincil (dolaylı) olarak iki sınıfa ayrılmaktadır. Birincil etkiler depremin ulaşım, sanayi, enerji, konut ve altyapı gibi alanda yarattığı etkilerdir. İkincil etkiler ise birincil etkilerin sonucu meydana gelen makroekonomik değişimleri içermektedir. Depremden bir süre sonra meydana gelen büyüme, istihdam ve ödeme dengesiyle beraber değerlendirilen ikincil etkenlere; kamu harcamaları, enflasyon oranları, bütçe açığı ve salgın hastalıklar örnek gösterilebilir (Güvel, 2008). Depremin meydana geldiği bölgenin gelişmişlikle ilişkisi, depremin ülke üzerindeki ekonomik etkisini bölge ile sınırlandırmayarak ülke genelinde de büyük ölçekli ekonomik sonuçların oluşmasına sebep olmaktadır. Bu noktada, Kocaeli-Gölcük depremi Türkiye için ekonomik olarak stratejik sayllabilecek bir bölgede meydana geldiği için ülkemiz üzerinde ciddi ekonomik kayıplara neden olmuştur. 2020 Eylül ayı verilerine göre yeniden belirlenen kur çerçevesinde Kocaeli-Gölcük depreminin toplam maliyeti, Devlet Planlama Teşkilatı (DPT) verilerine göre 23 ila 29 milyar dolar, Dünya bankası verilerine göre 18 ila 31.2 milyar dolar, Türk Sanayicileri ve İş İnsanları Derneği (TÜSİAD) verilerine göre ise 31.2 milyar dolar olarak belirlenmiştir (TMMOB, 2012). Bu maliyetler göz önüne alındığında Kocaeli-Gölcük depremi, dünyada meydana gelen en maliyetli depremler arasında gösterilmiştir (TMMOB, 2012).

Depremlerin ekonomik etkilerinin yanında yarattığı sosyal ve psikolojik etkileri de oldukça önemlidir. Depremden etkilenen mağdurlar genellikle dört ayrı kategoriye ayrılır (Karka ve Akyılmaz, 2009). Bu kategoriler birincil, ikincil, üçüncül ve dördüncül kategori olarak adlandırılır. Birincil kategorideki mağdurlar deprem bölgesinde yaşayan bireylerdir. İkincil kategorideki 
Türkiye'de Deprem Performansına Dayalı Bina Kimlik Bilgilerinin Oluşturulmasına Yönelik Çalışma ve Öneriler

mağdurları ise birincil mağdurlarla ailevi ya da kişisel bağı olan bireyler oluşturmaktadır. Üçüncül kategori mağdurları depremzedelere yardım eden bireyler ve sivil toplum kuruluşu çalışanlarıdır. Depremin dördüncül ve son mağdurları ise deprem olayına medya yoluyla tanık olan tüm bireylerdir. Yapılan araştırmalara göre deprem yaşantısının bireyler üzerindeki psikolojik etkilerinin; kızgınlık ve duyguların bastırılamaması, ayrılık anksiyetesi, uzaklaşma ve pasiflik, yaşadığı için suçluluk duyma, çaresizlikle birlikte büyük acıların yaşanması olduğu saptanmıştır (İşmen, 2006).

\section{DEPREME DAYANIKLI KONUT}

$\mathrm{Bu}$ bölümde ülkemizde kullanılan mevcut taşıyıcı sistemlere ait bilgiler verilecek, deprem yönetmeliklerinin kısa tarihçesi anlatılarak bina envanteri çalışmasının detaylarına girilecek ve deprem performanslarının belirlenmesine yönelik metotlara değinilecektir.

\subsection{Mevcut Taşıyıcı Sistemler}

Türkiye'de ilk bina sayımı 1965 yılında Devlet İstatistik Enstitüsü (DİE) tarafından yapılmış ve bunu 1970 ile 1984 yılları izlemiștir. DİE tarafından yapılan en son sayım ise 2000 yılına aittir. 2005 yılında DİE, Türkiye İstatistik Kurumu (TÜİK) olarak yeniden yapılanmış ve bina verileri bu yıldan sonra TÜİK internet sitesi üzerinden erişime sunulmuştur (Tunç, 2015). 2000 yılında yapılan sayıma göre toplam bina sayısı 7 milyon 838 bin 675 bina olarak tespit edilmiştir (Gökçe, 2011). 2019 yılı verilerine göre ise toplam bina sayısında \%21.4 artışla 9 milyon 513 bin 627 sayısına ulaşılmıştır. TÜİK verilerine göre 2002-2019 yılları arasında 1 milyon 588 bin 797 yapı için tamamen veya kısmen biten yeni ve ilave yapılar adı altında 'Yapı Kullanma İzin Belgesi' düzenlenmiştir (TÜİK, 2020). Taşıyıcı sistemlerine göre bu yapılar, yığma, iskelet-çelik, iskeletahşap, iskelet betonarme, kompozit ve prefabrik yapı türleri olarak sınıflandırılmıştır. 2002-2019 yılları arasında yapı kullanma izin belgesi düzenlenen yapılar içinde yapı türü olarak en yaygın kullanılan \%91,5 ile iskelet-betonarme yapıdır; bunu \%4,7 ile yığma yapı, \%1,3 ile iskelet-çelik yapı takip etmektedir. Şekil 2'de 2002-2019 yılları arasında inşa edilen yapıların taşıyıcı sistemlerine göre ylllar içindeki değişimi görülmektedir. Bu grafikte iskelet-betonarme ile inşa edilen binalar sayıca diğerlerine göre yaklaşık 15 kat fazla olduğu için gösterilmemiştir. Böylelikle diğer tür taşıyıcı sistemlerin birbirlerine göre değişimleri daha anlaşılır kılınmaya çalışılmıştır. Taşıyıcı sistemler içinde en yaygın olarak kullanılan iskelet-betonarme ile inşa edilen yapıların 1992 ila 2019 yılları arasındaki değişimi ise Şekil 3'de gösterilmiştir.

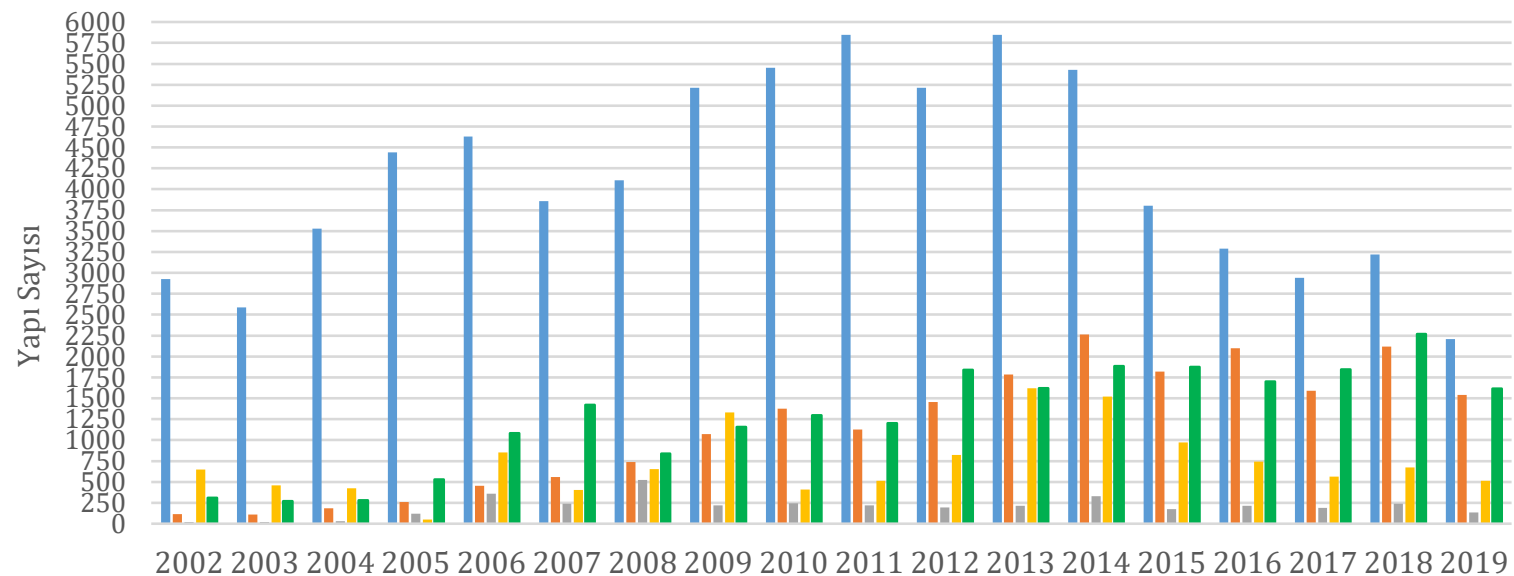

Yll

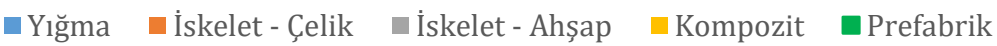

Şekil 2. Taşıyıcı sistemlerin yıllara göre değişimi (2002-2019) 


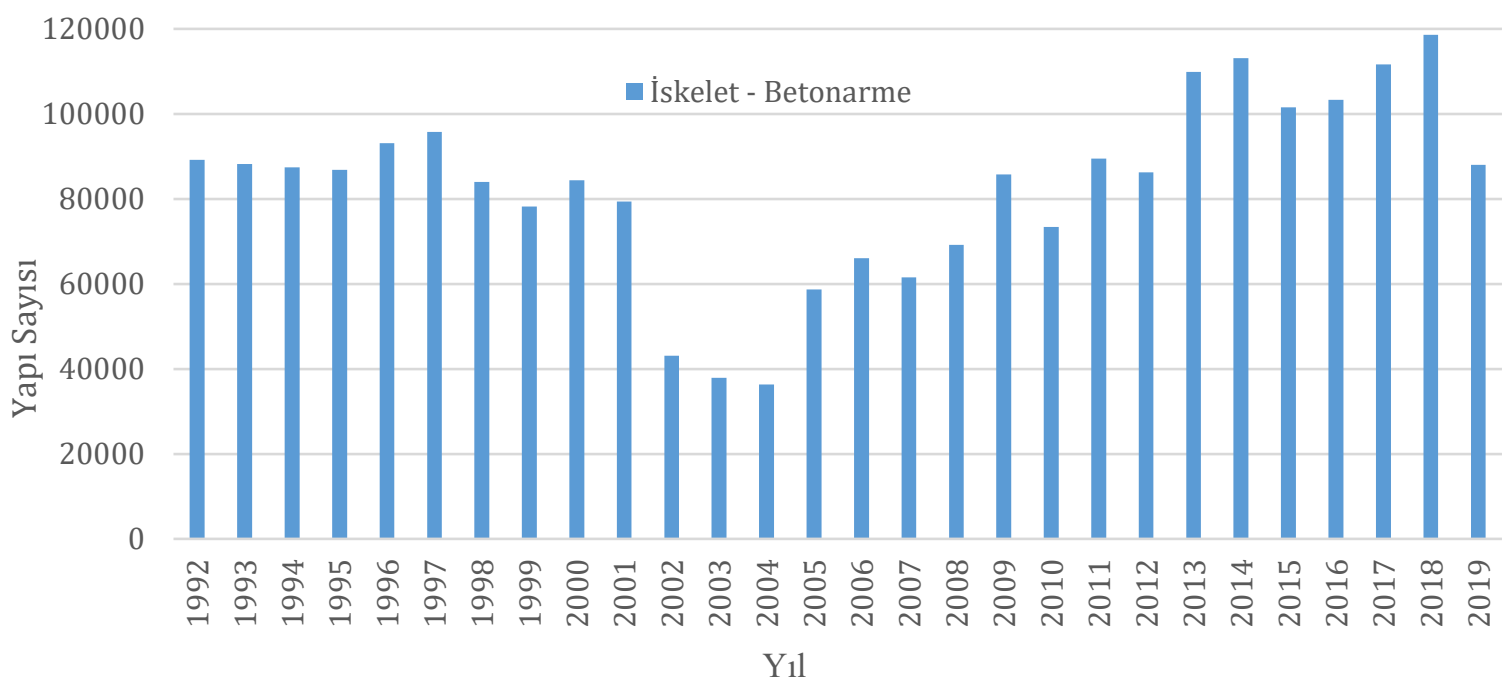

Şekil 3. İskelet-Betonarme taşıyıcı sistem (1992-2019)

\subsection{Türkiye'deki Deprem Yönetmelikleri ve Kısa Tarihçesi}

Türkiye'de ilk deprem yönetmeliği 1939 Erzincan depreminden sonra 1940 yılında yürürlüğe girmiştir ve yıllar içerisinde meydana gelen depremlerde can ve mal kayıplarının artmasıyla ihtiyaçlar doğrultusunda 9 kez değişime uğrayarak günümüze kadar gelmiştir (Pampal ve Özmen, 2007; Tunç ve Tunç, 2021). Meydana gelen depremler, teknolojik gelişmeler ve bilimsel çalışmaların sonucunda deprem yönetmelikleri de tarih içerisinde evrimsel döngü sürecini yaşamış ve yaşamaktadır (Tunç, 2020). Günümüzde kullanılan 2018 Türkiye Bina Deprem Yönetmeliği (TBDY18) ise diğerlerinden farklılık göstererek performansa dayalı analiz ve değerlendirme ilkelerine uygun olarak oluşturulmuştur. Bu yönetmelikte ilk defa temel yalıtımlı ve yüksek bina tasarımına ait özel bölümler yer almaktadır. TBDY18 ile birlikte 1940 yılından bu yana kullanılan deprem bölgeleri haritasından tamamı ile vazgeçilerek tasarlanacak deprem yer hareketi düzeyine bağlı olarak deprem tehlike haritaları oluşturulmuştur (Şekil 4 ve 5).

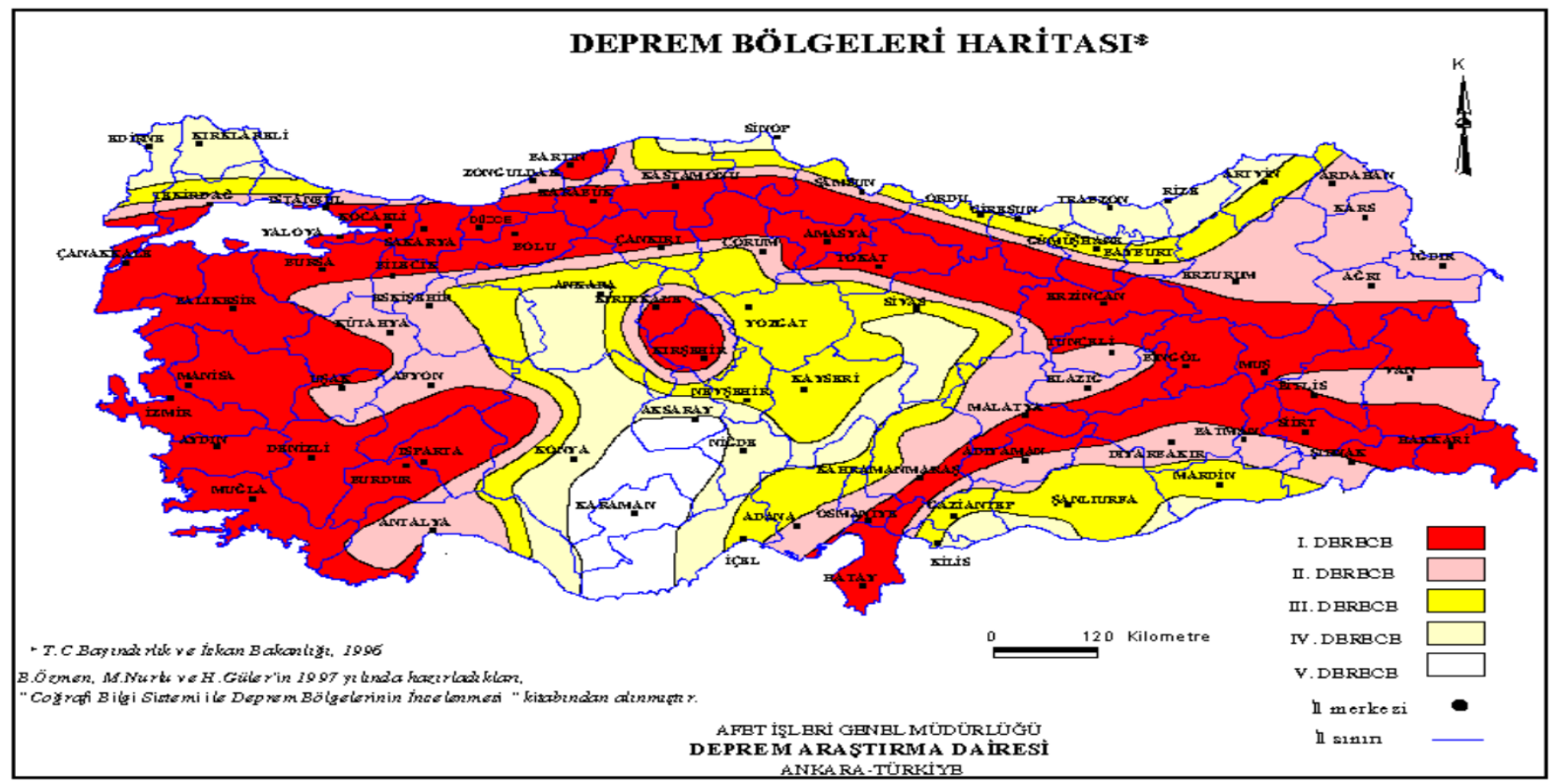

Şekil 4. 2007 deprem yönetmeliğine göre Türkiye deprem bölgeleri haritası (T.C. Bayındırlık Bakanlığı, Afet İşleri Genel Müdürlüğü , 1996) 
Türkiye'de Deprem Performansına Dayalı Bina Kimlik Bilgilerinin Oluşturulmasına Yönelik Çalıșma ve Öneriler

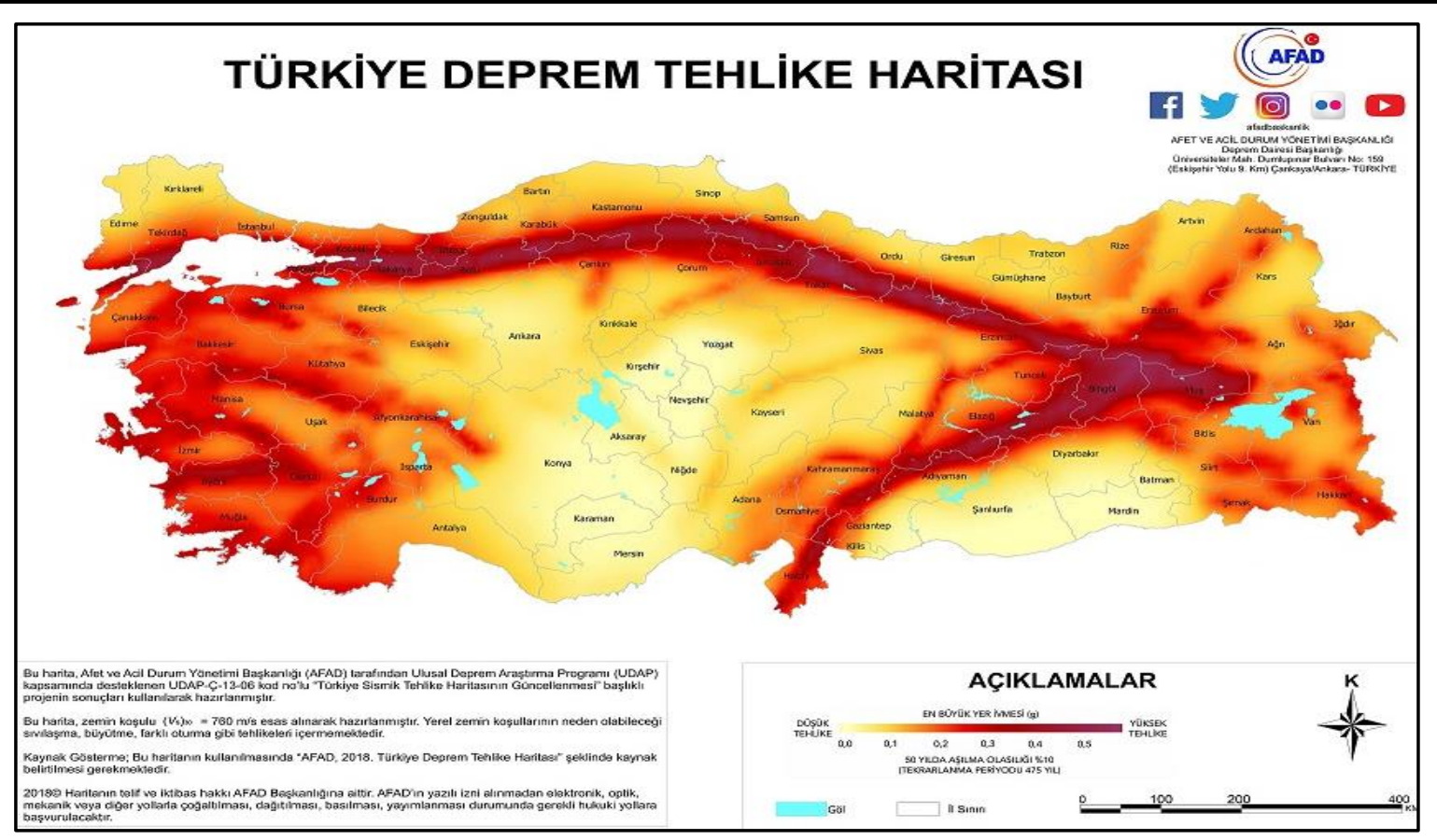

Şekil 5. 2018 deprem yönetmeliğine göre 50 yılda aşılma olasılı̆̆ı \%10 olan depremler için hazırlanan Türkiye deprem tehlike haritası (AFAD, 2018)

Deprem yönetmeliklerinin genel amacı depreme dayanıklı yapıların tasarım ve taşıması gereken fiziki ve teknik özelliklere yönelik kuralların tarifi olarak tanımlanabilir. Ülkemizde kullanılan deprem yönetmelikleri aşağıdaki listede kronolojik olarak sıralanmıştır.

- 1940 - Zelzele Mıntıkalarında Yapılacak İnşaata ait İtalyan Yapı Talimatnamesi (Pampal ve Özmen, 2007)

- 1944 - Zelzele Mıntıkaları Muvakkat Yapı Talimatnamesi (Pampal ve Özmen, 2007)

- 1949 - Türkiye Yersarsıntısı Bölgeleri Yapı Yönetmeliği (Pampal ve Özmen, 2007)

- 1953 - Yersarsıntısı Bölgelerinde Yapılacak Yapılar Hakkında Yönetmelik (Pampal ve Özmen, 2007)

- 1961 - Afet Bölgelerinde Yapılacak Yapılar Hakkında Yönetmelik (T.C. Resmi Gazete, 1961)

- 1968 - Afet Bölgelerinde Yapılacak Yapılar Hakkında Yönetmelik (T.C. Resmi Gazete, 1968)

- 1975 - Afet Bölgelerinde Yapılacak Yapılar Hakkında Yönetmelik (T.C. Resmi Gazete, 1975)

- 1998 - Afet Bölgelerinde Yapılacak Yapılar Hakkında Yönetmelik (T.C. Resmi Gazete, 1997)

- 2007 - Deprem Bölgelerinde Yapılacak Binalar Hakkında Yönetmelik (T.C. Resmi Gazete, 2007)

- 2018 - Türkiye Bina Deprem Yönetmeliği (T.C. Resmi Gazete, 2018)

Geçmişten günümüze kadar olan deprem yönetmelikleri genel hatlarıyla incelendiğinde, 1940 ve 1944 deprem yönetmeliklerinde daha çok mimari konulara yer verilmiş ve genel yapısal kurallardan bahsedilmiştir. Bunun temel sebebi ise o dönemlerde yığma taşıyıcı sisteme sahip yapıların sayıca oldukça fazla olmasıdır. 1949 deprem yönetmeliği ile birlikte 1 . ve 2. deprem bölgeleri yüzeysel olarak belirlenmiş ve ilk defa deprem hesabının nasıl yapılması gerektiğine dair 
bilgiler ayrıntılı olmasa da yönetmelikte yer almıştır. 1953 deprem yönetmeliğinde deprem bölgeleri için deprem katsayısı, yapı türleri belirlenmiş ve zemin konusu işlenmiștir. 1961 yönetmeliğinde, deprem kuvveti hesaplanması bir adım daha ileriye taşınarak deprem katsayısı; bina yüksekliği, yapı ve zemin cinsi ile ilişkilendirilmiștir. Aynı yönetmelikte deprem bölgesinde yapılacak yapılar ile ilgili çalışmalara da yer verilmiştir. 1968 deprem yönetmeliği ile birlikte betonarme inşaat elemanlarının kurallarından bahsedilmiş ve deprem hesapları daha ayrıntılı olarak izah edilmiştir. 1975 deprem yönetmeliği ile ülke 4 deprem bölgesine ayrılmış ve yapıya etkiyen deprem kuvvetleri ise birçok parametre göz önünde bulundurularak hesaplanmaya başlanmıştır. 1998 ve 2007 deprem yönetmelikleri önceki deprem yönetmeliklerine göre çok daha ayrıntılı olarak hazırlanmış ve mevcut yapıların performanslarının tespit edilmesi ve güçlendirilmesi ile ilgili kurallar ilk defa 2007 deprem yönetmeliğine eklenmiştir. Yürürlükte olan 2018 deprem yönetmeliği ise diğerlerine göre çok daha ayrıntılı deprem yönetmeliği olarak karşımıza çıkmaktadır. Bu yönetmelikle birlikte yeni yapılacak binaların deprem etkisi altında tasarımı ile mevcut binaların değerlendirilmesi ve güçlendirme tasarımı, yerinde dökme ve ön üretimli betonarme, çelik, hafif çelik, yığma ve ahşap malzemeden yapılan binalar ile yüksek binaların ve yalıtımlı binaların da deprem etkisi altında tasarımını yapmak için gerekli hesap yöntemleri açıklanmıştır.

\subsection{Hedef Bina Envanteri}

Türkiye'deki mevcut yapı stoku 1998, 2007 ve 2018 yıllarına ait deprem yönetmelikleri esas alınarak 4 ayrı dönemde ele alınmıştır: 1997 öncesi, 1997 ve 2007 arası, 2007 ile 2019 arası ve son olarak 2019 sonrası inşa edilen binalar dönemi. Bu sınıflandırmada 1997 öncesi inşa edilen binalar yapısal tasarım ve inşa yöntemleri açısından milat kabul edilmiştir. Bu kabulün ana sebebi ise Türkiye'deki 1998 deprem yönetmeliğinin kendisinden önceki yönetmeliklere göre çok daha detaylı ve kapsamlı olmasıdır (1998 deprem yönetmeliği ilk defa 1997 yılında yayınlanmış; 1998 yılında ise değişikliklerle beraber tekrar ilan edilmiştir. Bu yüzden binalar için başlangıç tarihi olarak 1998 deprem yönetmeliği yılı esas alınmıştır).

\subsubsection{7 Öncesi İnşa Edilen Binalar}

Ülkemizde meydana gelen depremlerde en riskli olarak değerlendirilen binalar 1997 öncesi inşa edilmiş binalardır. Bu dönemin riskli olarak değerlendirilmesi ise deprem yönetmeliklerinin yeterli ayrıntıya sahip olmaması, yapı denetim mekanizmasının oluşmaması, hazır beton ve nervürlü demirin yaygın olarak kullanılmamasıyla ilişkilidir. Hazır betonun 1980'lerden sonra kullanılmaya başlandığı bilinmektedir, fakat yaygın olarak kullanılmaya başlandığı dönem ise özellikle 1999 yılında meydana gelen Marmara depremi sonrasıdır. TÜíK verilerine göre 19541997 yılları arasında 3,6 milyon civarında bina için yapı ruhsatı verilmiştir. Riskli binaların güçlendirilmesi ve kentsel dönüşüm projesi kapsamına alınarak iyileştirilmesi zaruri bir durum haline gelmiştir. Kaldı ki 1990 öncesi döneme ait binalar ile ilgili yaşanılan yapısal sorunlara 2020 Elazığ-Sivrice ve 2020 Seferihisar, İzmir açıklarında meydana gelen Ege Denizi depremlerinde yıkılan ve hasar alan yapılarda da sıklıkla rastlamaktayız. Hasar alan veya yıkılan bu binaların büyük bir çoğunluğunun inşa edildiği dönemde yapı denetimin bulunmaması, hazır beton üretiminin henüz başlamamış olmaması ve donatı olarak nervürsüz (düz) donatı kullanımına yönelik yürürlükteki 1975 deprem yönetmeliğinin izin vermesi etkili olmuştur (Mertol vd., 2020).

\subsubsection{7-2007 Arası İnșa Edilen Binalar}

1998 deprem yönetmeliğinin yürürlüğe girmesi ve hazır beton uygulamasının yaygınlaşmaya başlaması ile birlikte önceki döneme göre nispeten daha sağlam binalar inşa edilmeye başlandığı görülmektedir. 1998 deprem yönetmeliğiyle birlikte 1. ve 2. deprem bölgelerinde en az C20, diğer deprem bölgelerindeki yapılarda ise en az C16 beton sınıfının kullanılması zorunlu hale getirilmiştir. Bilindiği üzere beton, Türkiye'de en yaygın olarak kullanılan taşıyıcı yapı malzemesi olup kalitesindeki ve dayanımındaki düşüklüğün betonarme yapısal elemanların göçme riski üzerindeki etkisi de tartışılmaz bir gerçektir (Uğurlu, 2013). Bu dönemde gerçekleşen konvansiyonel betondan hazır beton üretimine geçiş süreci kullanılan beton kalitesinin artmasını 
Türkiye'de Deprem Performansına Dayalı Bina Kimlik Bilgilerinin Oluşturulmasına Yönelik Çalışma ve Öneriler

sağlamıştır (Özkul, Uçar, Şaşmaz ve Yanpınar, 2011). Zaman içinde ilerleyen ve gelişen teknoloji ile birlikte paket programların inşaat sektörü tarafından yaygın kullanılmaya başlanması ise daha ileri ve güvenilir yapısal analizleri mümkün kılmıștır. Ayrıca 2001 yılında yapı denetim mekanizmasının oluşturulmasıyla birlikte özellikle saha uygulamalarındaki eksikliklerin ve yanlışlıkların önlenmesi amaçlanarak daha güvenilir projeler inşa edilmeye başlanmıştır. TÜi̇K verilerine göre bu 10 yıllık dönemde tamamen ve kısmen biten yeni binalar adı altında 730 bin civarında bina için yapı kullanma izin belgesi düzenlenmiştir (TÜíK, 2020). Deprem performansı açısından değerlendirildiğinde bu dönemde inşa edilen binalar ikinci öncelikli olarak ele alınması gereken binalardır.

\subsubsection{7-2019 Arası İsşa Edilen Binalar}

1998 deprem yönetmeliğini takip eden 2007 yılı deprem yönetmeliğinin (ABYBHY07) yürürlüğe girmesiyle mevcut yapıların performanslarının tespit edilmesi ve güçlendirilmesi de zorunlu hale gelmiştir. Bu yönetmelik ile birlikte kentsel dönüşüm kavramı daha sık duyulmaya başlanmış ve güçlendirilemeyecek kadar hasarlı olan binaların yıkılıp yerine yeni binaların inşa edilmesi amaçlanarak olası bir depremde meydana gelebilecek can ve mal kaybının önlenmesi amaçlanmıştır. $\mathrm{Bu}$ yıllar arasında inşa edilen toplam 1 milyon 322 bin 60 bina, deprem performansları açısından üçüncü öncelikli binalar olarak değerlendirilmelidir (TÜİK, 2020).

\subsubsection{Sonrası İnşa Edilen Binalar}

1 Ocak 2019 tarihinde Türkiye Bina Deprem Yönetmeliği (TBDY18) yürürlüğe girmiştir. TBDY18, 1940 yılından bu yana yayınlanan deprem yönetmelikleri arasında en kapsamlı olanıdır. Bu yönüyle uygulamada ve kalite kontrol aşamasında eksiklik olmadığı sürece bu yönetmeliğe göre inşa edilen binalarda, olası bir deprem sonrasında yapısal yönden ciddi bir riskle karşılaşılmayacağı ya da diğer bir deyişle yıkılma ve göçmenin önlenebileceği öngörülmektedir. TÜİK verilerine göre 2019 yılında inşa edilen bina sayısı 90 binden fazladır (TÜİK, 2020). Dolayısı ile bu binalar deprem performansları açısından önceki yıllarda inşa edilen binalara göre çok daha az deprem riski taşıyan binalar olup dördüncü ve en son önceliğe sahip binalar olarak değerlendirilmelidir.

\subsection{Riskli Yapı ve Deprem Performansları}

Ülkemizde deprem karşısında oluşabilecek risklerin azaltılması ya da ortadan kaldırılması hususunda şu ana kadar bazı önemli adımlar atılmıştır. Bunlardan birisi zorunlu deprem sigortasıdır. Deprem riskine karşı depremin etkilerinin ekonomik açıdan azaltılabilmesi için 17 Ağustos 1999 Marmara depreminden sonra Doğal Afet Sigortalar Kurumunun (DASK) üstlendiği zorunlu deprem sigortası hayata geçirilmiştir (Tunç, 2015). 2018 DASK verilerine göre poliçe sayısının 8,8 milyon olduğu ve zorunlu deprem sigortasına sahip konutların oranının \%50'ye yükseldiği tespit edilmiştir (DASK, 2018). Bu konuda atılan diğer bir önemli adım ise riskli binaların taşıdığı riskleri büyük ölçüde kentsel dönüşüm adı altında yok etmektir. Riskli yapı, 6306 sayılı Afet Riski Altındaki Alanların Dönüştürülmesi hakkındaki kanunda "riskli alan içinde veya dışında olup ekonomik ömrünü tamamlamış olan ya da yıkılma veya ağır hasar görme riski taşıdığı ilmi ve teknik verilere dayanılarak tespit edilen yapı" olarak tanımlanmıștır (T.C. Çevre ve Şehircilik Bakanlığı, 2012). 2012 yılında riskli yapıların dönüştürülmesi ve mevcut yapı stokunun iyileştirilmesi amacı ile kentsel dönüşüm yasası yürürlüğe girmiştir. 2019 yılı verilerine göre kentsel dönüşüm uygulamasıyla yaklaşık 7 milyona yakın riskli konutun dönüștürüleceği ya da yıkılıp tekrar yapılacağı belirlenmiştir (T.C. Çevre ve Şehircilik Bakanlığı, 2019). Ayrıca öncelikli olarak belirlenen 1.5 milyon riskli binanın dönüşümünün 5 yıl içinde yapılması da planlanmaktadır (T.C. Çevre ve Şehircilik Bakanlı̆̆ı, 2019). Türkiye genelinde 2020 Ocak ayı itibariyle kentsel dönüşüm kapsamında riskli olarak tanımlanan 631.723 binanın 515.813'ü ise yıkılmıştır (Tabak, 2020). 


\subsubsection{Binaların Deprem Performanslarının Belirlenmesine Yönelik Kullanılan Yöntemler}

Depremlerin yerleşim bölgelerinde meydana getireceği hasarları ve can kayıplarını en aza indirgemek amacı ile mevcut binaların deprem performanslarının değerlendirilmesi özellikle 1999 yılında meydana gelen Düzce depreminden sonra önemli bir araştırma konusu haline gelmiştir. $\mathrm{Bu}$ doğrultuda Türkiye'deki mevcut binaların deprem performanslarının değerlendirilmesi için hızlı ve detaylı birçok tarama yöntemi uzmanlar tarafından geliştirilmiştir. Bu tarama yöntemlerinden biri Japon Sismik Tarama yöntemi esas alınarak geliştirilen Deprem Güvenliği Tarama Yöntemi'dir (Boduroğlu ve Özdemir Çağlayan, 2007). Bu yöntem, altı katlı betonarme çerçeve, perde duvar-çerçeve veya sadece perde duvarlardan oluşan taşıyıcı sisteme sahip bodrum kat harici altı ve/veya daha az katlı bina türü yapıların hızlı taraması için kullanılmıștır. Deprem Güvenliği Tarama Yöntemi yapının taşıyıcı sisteminin, yaşının ve fiziksel durumunun incelenmesi sonucunda deprem performansını gösteren I indeksinin belirlenmesini amaçlamaktadır. Deprem performansını gösteren indeks ile yapı için dikkate alınan karşılaştırma indeksi ID'nin karşılaştırılması sonucunda binanın deprem güvenliği tahmin edilmeye çalışılmıştır. Diğer bir tarama yöntemi ise kentsel yapı stoklarının deprem risklerinin belirlenmesi amacı ile kullanılan Sokaktan Tarama Yöntemi'dir (Sucuoğlu, 2007). Bu yöntemde uzman kişilerce doğrudan sokaktan gözlemlenen bina parametreleri (görünen yapı kalitesi, ağır çıkmalar, yumuşak katlar, bina serbest kat sayısı gibi) kullanılarak bir risk sıralaması yapılmaktadır. Bu tarama türünde bina başına ihtiyaç duyulan süre ise yaklaşık 10 dakika olarak tanımlanmıştır. Sokaktan toplanan veriler doğrultusunda her bina için bir risk performans skoru hesaplaması yapılmakta ve bu risk performans skorları binaların bulundukları bölgede beklenen deprem büyüklüğü (magnitüdü) ve binaların deprem anında beklenen performanslarına bağlı olarak risk önemlerini belirlemek için kullanılmaktadır.

Binaların deprem performanslarının belirlenmesinde kullanılan bir başka yöntem ise Türkiye Bina Deprem Yönetmeliği 2018'in (TBDY18) 15. bölümünde verilen kurallara göre belirlenen yöntemdir. Bu yöntemde binalardan sınırlı ya da kapsamlı bilgi düzeyinde veri toplanarak doğrusal veya doğrusal olmayan yöntemlere göre performans düzeyleri belirlenir. Performans düzeyleri belirlenen binalardan güçlendirme ihtiyacı duyulanları için yine aynı bölümde önerilen yöntemlere uygun olarak gerekli güçlendirme çalışmaları yapılır. TBDY18'e göre tariflenen yöntemin bir üst paragrafta verilen diğer yöntemlere göre en önemli avantajı, detaylı veri toplama sürecine bağlı olarak ortaya çıkan gerçekçi duruma daha yakın bina davranış biçiminin belirlenmesidir. Veri toplama sürecinde takip edilen hasarlı yöntemlerin özellikle oturum halindeki binalarda yarattığı sorunlar ve bina başına ihtiyaç duyulan toplam sürenin oldukça uzun olması bu yöntemin olumsuz yanlarını teşkil etmektedir.

Binaların deprem performanslarının belirlenmesinde kullanılan etkili bir diğer yöntem ise jeofizik yöntemlerdir. Jeofizik yöntemlerden olan sismik (ultrasonic puls hız yöntemi, kırılma ve yansıma yöntemi), elektrik (özdirenç) ve elektromanyetik (ferroscan) yöntemler ile Schmidt çekici yöntemi binalara hasar vermeden tahribatsız olarak uygulanabilmektedir. Bu yöntemler aracılığı ile binaların sağlamlık testleri hızlı, ekonomik ve doğru olarak yapılabilmektedir (Pekşen ve Așcı, 2015; Ercan, 2003).

2019 yılı itibarı ile Türkiye'deki toplam bina sayısı 9 milyon 513 bin 627'dir (TÜİK, 2020). Bu sayının \%78,5'i ise özellikle risk grubuna girme ihtimali yüksek 1997 deprem yönetmeliği öncesinde yapılan binalardan oluşmaktadır. Dolayısı ile performans değerlendirmesi yapılacak yaklaşık olarak toplam 7.5 milyona yakın bina bulunmaktadır. Bu binaların TBDY18'e göre performans değerlendirmesinin tamamlanması için 5 yıllık bir süre bile öngörülse ihtiyaç duyulan ekip sayıları pratik olmayan bir hale bürünmektedir. Yazarlar, bu sürecin zaman ve ekip açısından en optimum düzeyde işlemesine yönelik olarak ya mevcut tarama yöntemlerinin kullanılması ya da daha pratik bir yöntemin mutlaka geliştirilmesi gerektiği görüşündedir. 
Türkiye'de Deprem Performansına Dayalı Bina Kimlik Bilgilerinin Oluşturulmasına Yönelik Çalıșma ve Öneriler

\section{TÜKETICININ DEPREM KONUSUNDA BILGILENDİRILMESI}

Türkiye'nin depremselliğinden dolayı deprem kavramının önemi ve etkileri hayatımızın her anında karşımıza çıkmaktadır. Özellikle 1999 yılında meydana gelen depremlerle birlikte oluşan can ve mal kayıplarının fazlalığı, bireylerin depremin ciddiyetini kavramasını sağlamış ve yıkıcı etkilerinden kaçınmak için birtakım önlemlerin alınmasının gerekli olduğunu ortaya koymuştur. $\mathrm{Bu}$ doğrultuda geçmişten günümüze deprem ve etkilerinden korunmak, depreme hazır olmak amacıyla birçok öneri sunulmuştur. Deprem tehlikesine maruz yerleşimler için Yerel Deprem Puanı yönteminin geliştirilmesi bu önerilerden biridir. Bu öneri kapsamında yapılacak çalışma ile yerel deprem puanına göre bölgelerin depreme hazırlıklı olup olmadığı yönünde sonuca ulaşllabileceği belirtilmiştir (Tokgöz ve Bayraktar, 2019). Kamu ve özel sektör kurum ve kuruluşları ise gerek deprem yönetmelikleri gerekse yapı denetimlerle birlikte kaliteli mühendislik uygulamalarının yapılmasını denetleyerek riski azaltmaya çalışmıştır. Fakat bu konuda tüketici maalesef kapsam dışı tutulmuş ve ihtiyaç duydukları teknik bilgiye nasıl ulaşmaları gerektiği konusunda da herhangi bir yasal çalışma henüz yapılmamıştır. Tüketicilerin doğru şekilde bilgilendirilmesi için yapılacak çalışmalar deprem bilinçlendirme sürecinin en önemli kısmını oluşturur. Bu bilgilendirmeyi farklı kitlelere farklı şekilde hitap ederek toplumun tümüne ulaştırmak ise arzulanan ana hedeftir. Aşağıdaki alt başlıklarda bu soruna yönelik çözüm önerilerine ait detaylar verilmiştir.

\subsection{Deprem Ĕ̈itim Seminerleri}

Tüketicilerin bilgilendirilmesi aşamasında öncelikli olarak ilkokul, ortaokul ve lise öğrencilerine deprem konusunda en az bir dönemlik ders verilmesi önerilebilir. Ders içeriğinde Türkiye'nin jeopolitik konumu, depremselliği, ülkemizde geçmișten günümüze meydana gelen depremler ve bu depremlerin Türkiye üzerindeki etkileri anlatılabilir. Günümüzde okullarda yapılan deprem tatbikatları yerine AFAD'a ait gezici tırlardaki deprem simülasyonları kullanılarak öğrencilerin suni depremi hissetmesi ve böylelikle deprem anında ve sonrasında ne yapmaları gerektiği hususunda bilinçlendirilmeleri sağlanabilir. Uygulamanın Türkiye geneline yaygınlaştırılması ile tüm okulların bu çalışmadan faydalanmasına imkân sunulabilir. Ev hanımları, yaşlılar, aktif olarak çalışma hayatında yer alan ya da yer almayan bireyler için de belediyeler ve AFAD tarafından muhtarlar ve apartman yöneticileri aracılığıyla bu bireylere ulaşılarak zorunlu deprem eğitimlerine katılmaları sağlanıp teşvik edilebilir. Eğitimlerin içerik açısından özellikle deprem anında ve sonrasında yapılması gerekenler üzerine yoğunlaşması sağlanılabilir. Hatta okullar için önerilen AFAD gezici tırları ile deprem simülasyon uygulamasının bu amaca hizmet etmek için kullanımı da desteklenebilir. Eğitime katılanlar için katılım sertifikası düzenlenerek bu eğitimlerin her yıl tekrarlanmasıyla deprem kavramının güncelliğini koruması amaçlanabilir. $\mathrm{Bu}$ eğitimlerle birlikte belki de depremi hiç yaşamamış kişilerin bile bilinçlenmesi sağlanabilir.

\subsection{Kamu Spotu}

Tüketicilerin deprem hakkında bilgilendirilmesi için kullanılacak bir diğer yöntem de basın-yayın organları aracılığı ile topluma deprem kavramının önemini, etkilerini ve sonuçlarını anlatmaktır. Bunun için en etkili çözüm yolu kamu spotudur. Kamu spotları izleyici üzerinde bıraktığı etkiden dolayı toplumun her kesimine aynı anda hitap edebilmek adına kullanılabilecek en elverişli yöntemlerden biridir. Kamu spotlarının içeriği deprem anını yaşayan bir insanın o andaki çaresizliği, konutu hakkındaki endișeleri ve deprem anında yapması gerekenlere yönelik olacak şekilde oluşturulabilir. Böylece kamu spotlarını izleyen bireyler deprem anındaki süreçle ilgili bilgi sahibi olacak hatta yaşamaları muhtemel olan depremlerle ilgili önlem bile almaya başlayacaklardır.

\subsection{Yükseköğretim Kurumlarının Bilgilendirilmesi}

Yükseköğretim kurumlarında eğitim alan öğrencilerin deprem hakkında bilgilendirilmesi hem bilinçli bir kesimin oluşması için hem de bu bireylerin farkındalıklarının yüksek olması açısından 
önemli bir adımdır. Bu bilgilendirmenin sağlanabilmesi için bölümlerin ders müfredatlarına 1 dönem zorunlu teorik ve 1 dönem seçmeli uygulama dersi olarak deprem dersi eklenebilir. Zorunlu teorik ders kapsamındaki deprem dersinde Türkiye'nin depremselliği, geçmişten günümüze yaşanan depremler, deprem anında ve sonrasında yapılması gerekenler ile ilgili bilgiler verilebilir. Seçmeli uygulama dersinde ise deprem sırasında veya hemen sonrasında çöken binalardan bireylerin nasıl kurtarılması gerektiği, çökmemiş ama hasar durumu yüksek olan binalardan bireylerin tahliyesi, deprem sonrasında depremden az, orta ve çok derecede etkilenen bireylere nasıl müdahale edilmesi gerektiğine yönelik bilgiler verilebilir. Seçmeli uygulama dersini alan öğrencilere AFAD tarafından hazırlanan sertifikalar verilerek topluma daha bilinçli ve duyarlı bir kitlenin katılımı sağlanabilir. Böylelikle olası bir depremde uzman ve görevlilerin yetersiz kalması durumunda sertifika sahibi olan öğrencilerden yardım talep edilerek uzman ekiplerin ve görevlilerin haricinde eğitimli bir kitlenin oluşumu desteklenebilir.

\section{BİLİNÇLİ TÜKETİCI VE BİNA KİMLIKK ÇALIŞMASI}

$\mathrm{Bu}$ bölümde depremler hakkında bilgilendirilen bireylerin bilinçli birer tüketici haline nasıl gelecekleri açıklanacak, bina kimlik çalışmasının hazırlanmasını gerektiren nedenlere değinilecektir.

\subsection{Bilinçli Tüketici}

Bina kimlik çalışması ile hedeflenen hem tüketicinin hem de uzmanlığı deprem ve yapı tasarımı alanında olan mühendis ve araştırmacıların doğru bilgiye en hızlı ve güvenilir şekilde ulaşmalarını sağlamaktır. Bu kapsamda tüketicinin oturduğu ya da oturmayı planladığı konut için gerekli bilgiye bilinçli bir tüketici olarak sahip olması hedeflenmektedir. Literatürde de tüketicinin konutu hakkında bilgilenmesinin gerekli olduğunu vurgulayan çalışmalar mevcuttur. Hatta yapılan bu çalışmalardan birinde tüketiciyi bilgilendirmek ve depreme karşı hazırlık yapmalarını hızlandırmak amacı ile bina girișlerine bilgi künyesi koyarak kullanıcıların binalara yönelik tutumlarını etkilemek önerilmiştir (Apaydın, 2020). Bilinçli tüketiciyi hazırlamak amacı ile önerilen fikir ve projelerin hayata geçirilmesi ve sürekliliğinin sağlanması makalenin de özünü teşkil eden bina kimlik çalışması için önemli bir aşamayı oluşturmaktadır. Bu aşamanın sağlıklı bir işleyişe kavuşması ile depreme yönelik bilgilerin ve korunmanın önemini kavrayan, deprem anında ve sonrasında ne yapması gerektiğini bilen bilinçli bireyler ortaya çıkmış olacaktır. Bilinçli bireyler ise bilinçli tüketici kavramının sağlam temeller üzerine oturtulmasını sağlayacaktır. Bilinçli tüketicinin yanında yapı tasarımına hâkim uzmanların da deprem öncesi veya sonrasında ihtiyaç duyacakları bilgiye ulaşmalarını sağlayan bina kimlik bilgileri oluşturulacaktır. Böylelikle deprem sonrasında ortaya çıkan hasarların tespit ve değerlendirilmesi için ihtiyaç duyulan bina bilgileri için de bir bilgi bankası hazırlanmış olacaktır.

İhtiyaçlar doğrultusunda gelişen ve değişen teknoloji ile birlikte sürdürülebilirlik kavramı da günden güne önem kazanmaktadır. İnşaat sektörünün çevreye, topluma ve ekonomiye olan etkileri göz önüne alındığında sürdürülebilirliğin önemi daha da artmaktadır (Gürgün et al., 2022). Sürdürülebilirliğe ulaşmak için bir bilgi bankasının oluşturulması bu anlamda da önemli bir görevin yerine getirilmesini sağlayacaktır. Bu kapsamda bina kimlik bilgilerini içerecek bir bilgi bankası ile deprem öncesinde ve sonrasında ihtiyaç duyulan bilgilere zaman ve maliyet kavramları minimize edilerek sağlıklı bir erişim sağlanmış olacaktır.

Yukarıda verilen bilgilerin ışığı altında bina kimlik çalışmasının amacı iki başlık altında toplanabilir. Bunlardan ilki tüketicilerin konut alımı ya da kiralama yapmadan önce alışılmışın dışına çıkan bir anlayış ile konutun mimari özelliğinden ziyade bina kimlik belgelerine bakmalarını sağlayarak tüketiciye konut özelinde teknik ve depreme dayanıklılık durumuna ait bilgi sunmaktır. Diğeri ise detaylı bilgiye ulaşabilen uzman mühendisler aracılı̆̆ı ile daha ayrıntılı bilgi ve değerlendirme raporları hazırlanarak tüm Türkiye için bir bina envanteri oluşturmaktır. 
Türkiye'de Deprem Performansına Dayalı Bina Kimlik Bilgilerinin Oluşturulmasına Yönelik Çalışma ve Öneriler

Hazırlanacak bina kimlik belgeleri ile birlikte pek çok eksik ve yanlış algının da önüne geçilmiş olacaktır. Bu algılardan en yaygın olanı yeni yapılan binanın ya da yüksek maliyetli konutların depreme en dayanıklı binalar olduğu algısıdır. Bir diğeri ise tünel kalıp binaların depreme en dayanıklı binalar olduğuna dair algıdır. Tüketicinin endişe duyduğu ve algı hatasına yol açan bir diğer husus ise sağlam zemine yapılmadığını düşündügü -fakat zemin iyileștirme ve kazıklı temeller konusunda bilgi sahibi olmadığı için- bir bina için "acaba çöker mi?" algısıdır. Bu gibi durumların da önüne geçmek, tüketici ve satan firmalar arasında daha şeffaf bir bağ kurmak adına bina kimlik çalışmasının yapılması önem teşkil etmektedir.

\subsection{Bina Kimlik Çalışması}

Bina kimlik çalışması kapsamında öncelikli olarak kamu kurumları, üniversiteler, ilgili meslek odaları ve belediyelerin ortak katılımları sonucu mevcut binalar için deprem değerlendirme raporlarının hazırlanması planlanmalıdır. Bu raporların hazırlanma sürecinde, zemin ve bina arasındaki yapısal etkileşimin bir bütün olarak ele alınması gerektiği için yerel zemin koşulları ile zemine ait dinamik ve statik özelliklere de deprem değerlendirme çalışmalarında yer verilmelidir. Mevcut bina stokunun oldukça fazla olması nedeni ile Çevre ve Şehircilik Bakanlığı tarafından yetkinliği olan firmalara gerekli lisanslar verilerek değerlendirme sürecinin kabul edilebilir zaman aralıklarına çekilmesi sağlanabilir.

Yapılan araştırmalar, incelemeler ve değerlendirmeler sonucunda binanın depreme dayanıklılığı için en uygun tanımlama yönteminin harf sistemi esasına dayalı yöntem olacağı öngörülmektedir. Bu kapsamda genel değerlendirme sonuçlarına bağlı olarak binalara diğer tüketim eşyalarında da kabul gören ve tüketicinin yakından aşina olduğu A-F arası bir harfin verilmesi planlanmıştır. Binanın depreme dayanıklılık durumuna göre ' $A$ ' harfi en dayanıklı, ' $F$ ' harfi ise en dayanıksız binayı temsil etmektedir. Bu tanımlamalara göre dayanıklılık düzeyi ' $D$ ' ve ' $E$ ' harfi olan binalarda en kısa sürede gerekli güçlendirme çalışmasının yapılması öngörülmektedir. Deprem performans düzeyi ' $F$ ' harfi olan binaların ise en riskli bina sınıflandırılmasına dâhil edilerek ya yıkılması ya da benzer durumdaki -varsa- civar binalar ile birlikte değerlendirilerek kentsel dönüşüm kapsamına alınması planlanmaktadır.

Bu çalışma kapsamında binalar için hazırlanan deprem performans raporlarının, tapu belgesine ek olarak tüketicilere satın alma sürecinde verilmesi düşünülmektedir. Raporların geçerlilik süresi için 5 yll öngörülmüş olup bu sürecin sonunda her 5 yılda bir raporların yenilenmesi planlanmıştır. Raporların denetiminin ise ilgili devlet kurumları ya da görevlendirilen uzmanlar tarafından gerçekleştirilmesinin uygun olacağı düşünülmektedir. 5 yılda bir hazırlanması gereken raporlardaki tariflenen sürenin büyük bir depremin hemen sonrasında veya uzmanlar tarafından talep edilmesi durumunda yeniden revize edilerek güncellenmesinin ise uygun olacağına karar verilmiştir.

Ayrıca bina kimlik çalışmasının çoklu katılımcı ilkesine uygun olarak yapılabilmesi için Çevre ve Şehircilik Bakanlığı, belediyeler, üniversiteler ile TMMOB’ye bağlı ilgili meslek odalarının da katılımcı olarak yer alması düşünülmektedir. Bina kimlik çalışmasının, mevcut binalar ve yeni yapılacak binalar olmak üzere iki kısımda değerlendirilmesi öngörülmektedir. Mevcut binalarda, bina kimlik çalışması uygulamasının tamamlanması için toplamda 10 yıllık bir sürenin yeterli olacağı düşünülmektedir. Bu süre zarfında kimlik belgelerinin, bakanlık tarafından onaylı kuruluşlar veya özel ya da tüzel kişi/kurumlar tarafından düzenlenmesi planlanmıştır. Yeni yapılacak binalara ait kimlik belgelerinin ise yapının kullanım izni aşamasında idareye sunulmasının uygun olacağı görüşü benimsenmiștir.

Binaların deprem performansları hazırlanırken bazı temel değişikliklere gidilmesinin gerekli olacağı düşünülmüştür. Bu değişikliklerden en önemlisi binalara verilmesi gereken yeni kimlik numarası kavramıdır. Ülkemizde, bina kimlik numarasının gerekliliği geçmiş dönemlerde de ele 
alınmış ve bina envanterinin oluşturulmasına yönelik örnek projeler üzerinde bu konuya ilişkin bazı öneriler sunulmuştur (Süer Toybıyık, 2017). Sunulan önerilerden bir diğeri ise bina envanteri oluşturulması için bina veri teması modelinin geliştirilmesidir. Bu bağlamda temel anlamda gerekli olan bina özellikleri ile kadastro ve adres veri temaları arasındaki ilișkileri tanımlayan bir model oluşturulması amaçlanmıştır (T.C. Çevre ve Şehircilik Bakanlığı, 2012). Fakat bu çalışmada da tüketicinin bilgilendirilmesi yine kapsam dışında tutulmuştur.

Önceki çalışmalar ve diğer ülkelerdeki örnekler göz önünde bulundurularak bina kimlik numaralarına yönelik yeni bir öneriye bu makalede yer verilmiștir. Bu öneriye göre günümüzde kullanılan türden bina veya apartman isimleri terk edilerek yerine 19 haneli kimlik numarasının binalara verilmesi planlanmıștır. Bu numaraların binanın bulunduğu il, ilçe, mahalle (köy), cadde ve sokak gibi coğrafi bilgiler ile birlikte yapıldığı yıl, yüklenici firma ve sorumlu mimara ait diğer teknik bilgileri de içerecek şekilde oluşturulması uygun görülmüştür. Şekil 6'de binalara verilecek kimlik numaralarına ait görsel yer almaktadır.

BINA KIMLIK NUMARASI

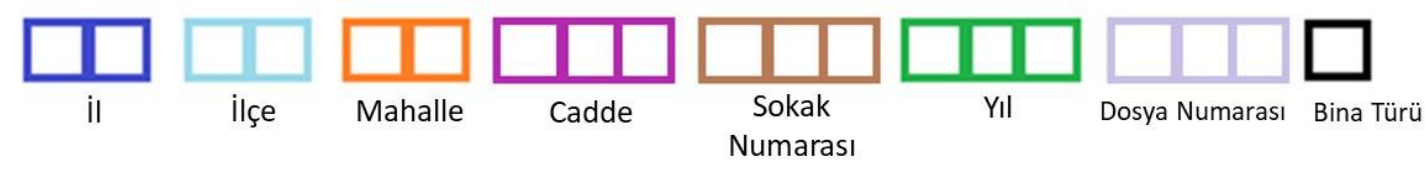

BINA KIMLIK NUMARASI ÖRNEK ÇALIŞMA

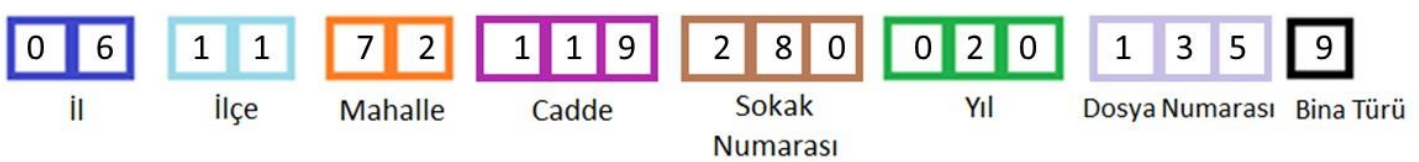

Şekil 6. Bina Kimlik Numarası

Bina kimlik numaraları kullanılarak değerlendirme veya teknik araştırma yapılan bir bina için dosya numarası bilgisi ile bina hakkında şu bilgilere de ulaşılması planlanmaktadır: (a) binanın deprem performansına ilişkin ayrıntılı rapor, (b) binayı yapan firma, (c) binanın ana yüklenicisi ve alt yüklenici firmaları, (d) projeye imza atan sorumlular, (e) binanın ısı ve su yalıtımının yapılıp yapılmadığı, (f) zemin türü, (g) kullanılan beton sınıfı ve (h) inşaat resimleri. Ayrıca, binanın yapım yılından itibaren daireleri satın alan ya da kiralayan tüketicilerin yaptırmış oldukları tadilatlar hakkında kısa bilgilerin de bina kimlik numarasına işlenmesinin uygun olacağı düşünülmektedir.

Tüketicilerin ihtiyaç duydukları zaman bina kimlik numaralarını kullanarak konutları hakkında ya da ileride konut almayı - kiralamayı düşündüklerinde ilgilendikleri konutun bina kimlik numarasını kullanarak yukarıda ifade edilen teknik bilgilere kısa sürede ulaşabilmeleri için bir mobil uygulamanın da geliştirilmesinin gerekli olduğu düşünülmektedir. $\mathrm{Bu}$ ihtiyaç doğrultusunda kullanılacak veri tabanının oluşturulabilmesi için konut inşaatı yapan firmalarla Çevre ve Șehircilik Bakanlığının işbirliği içerisinde olması önem arz etmektedir. Sürecin sağlıklı işlemesi için Çevre ve Şehircilik Bakanlığı tarafından mobil uygulamanın kullanımına ve gerekli bilgilerin sisteme girişine yönelik izlenecek yolları hedefleyen bir dizi eğitimin düzenlenmesinin gerekli olduğu düşünülmektedir. Son yıllarda inşaat sektörünün Gayrisafi Yurtiçi Hasıla (GSYH) içindeki payının düşmeye başlaması ve buna karşın inşaat mühendisliği bölümlerinden mezun 
olan mühendis sayısının artışı göz önüne alındığında, mühendislerin mevcut sistemde istihdamı ile ilgili önemli problemlerin ortaya çıktığı belirtilmiştir (Demirtürk ve Tunç, 2021). Bu sebeple Çevre ve Şehircilik Bakanlığı tarafından verilecek eğitimlerin öncelikli olarak yeni mezun ya da henüz iş tecrübesi edinememiş mühendislere yönelik olmasının bu kitlenin istihdamı için de önemli bir fayda sağlayacağı düşünülmektedir. Eğitimlerde başarılı olan adaylara mobil uygulamayı kullanmaya yetkili olduklarını belirten sertifika verilmesi öngörülmektedir. Sertifika sahibi olan adayların kura sistemi ile görevlendirilmesinin yine Çevre ve Şehircilik Bakanlığı tarafından yapılmasının uygun olacağı düşünülmektedir. Görevlendirilen mühendisler; belediyeler, ilgili meslek odaları ile inşaat firmalarındaki proje verilerine erişim sağlayarak bina kimlik numarasıyla hedeflenen teknik bilgilerin sisteme girişini yapmakla yükümlü olacaklardır. Bu sürecin birçok firmada eş zamanlı olarak ilerlemesiyle birlikte veri tabanının çok kısa bir zamanda oluşturulabileceği de öngörülmektedir.

Yukarıda detayları aktarılan bina kimlik çalışması ile birlikte nasıl ki araba satın alırken arabanın geçmişi ve hasarları gibi konularda kolaylıkla bu bilgilere ulaşılabiliyorsa konutlar için de benzer durumun tesis edilmesi planlanmaktadır. Bu noktada tüketiciye sadece binanın mimari özellikleri değil aynı zamanda teknik özellikleri de aktarılarak bilinçli bir tüketici kitlesinin oluşturulması hedeflenmektedir. Böylelikle tüketici, satın alacağı veya kiralayacağı binanın deprem performansını önceden öğrenip yeterli bilgiye sahip olacaktır. Bu kapsamda tüketiciye yeterli bilgiyi ulaștırmak için izlenecek hedef yol Şekil 7'da özetlenmiştir.

\subsubsection{Bina Kimlik Numarası Kullanımına ait Yurtdışı Örnekleri}

Bina kimlik numarası ya da benzer türden çalışmaların diğer ülkeler için de yapılıp yapılmadığı araştırılmıştır. Bu kapsamda Avusturya, Almanya, Güney Kore, Japonya, Norveç, Polonya, Hollanda ve Amerika Birleşik Devletleri (ABD) örnek olarak incelenmiştir. Bu ülkeler arasından Hollanda ve ABD'nin bina kimlik numarası geliştirdiği ve kullandığı tespit edilmiştir. Hollanda'da tek tip bina kimlik numarası kullanılırken Amerika'da bina kimlik numaralarının eyaletlere ve şehirlere göre farklılık gösterdiği görülmüştür. Amerika özelinde New York ve Atlanta şehirleri örnek iki şehir olarak incelenmiştir.

Hollanda'da bina kimlik çalışmasının temeli ulusal ölçekte bina ve adres bilgilerinin tutulduğu her binanın bir geometrisi ve kimlik numarasının yer aldığı Basisregistraties Adressen en Gebouwen (BAG) adı verilen sistemin oluşturulmasına dayanmaktadır (BAG, 2018). Bu sistemde binalara, her bir hanenin rakamlardan oluştuğu 16 haneli kimlik numarası ataması yapılmıştır. Bu 16 haneli bina kimlik numarası 3 bölümden meydana gelmektedir. Bina kimlik numarasının birinci bölümü olan ilk dört hanesi, Hollanda'da bulunan belediyelerin numaralarını temsil etmektedir. Hollanda'da belediyelere 0000 numarasından başlanarak sıralı olarak özgün numaralar verilmiştir. Örneğin binanın bulunduğu bölgenin ismi Onbekend ise bina kimlik numarasının ilk dört hanesi Onbekend belediyesine ait olan 0000 numarasıdır ya da binanın bulunduğu bölgenin ismi Amersfoort ise bina kimlik numarasının ilk dört hanesi Amersfoort belediyesine ait olan 0307 numarasıdır. Kimlik numarasının ikinci bölümü ise iki haneli olup, BAG sisteminde nesnenin özelliğine göre belirlenmektedir. Örneğin nesnenin özelliği konut ise bina kimlik numarasında ikinci bölüme 10 numarası yazılmaktadır. Son olarak üçüncü bölüm ise on haneden oluşmaktadır ve bu bölüm yapının seri numarasını oluşturmaktadır. Bina kimlik numarası tüketiciye binanın inşaat yılı, binanın durumu yani kullanımda olup olmadığı, posta kodu gibi konularda bilgi vermektedir. 


\section{KONUT ÖZELINDE TEKNIK BILGILERIN TÜKETICIYE ULAŞTIRILMA SÜRECi}

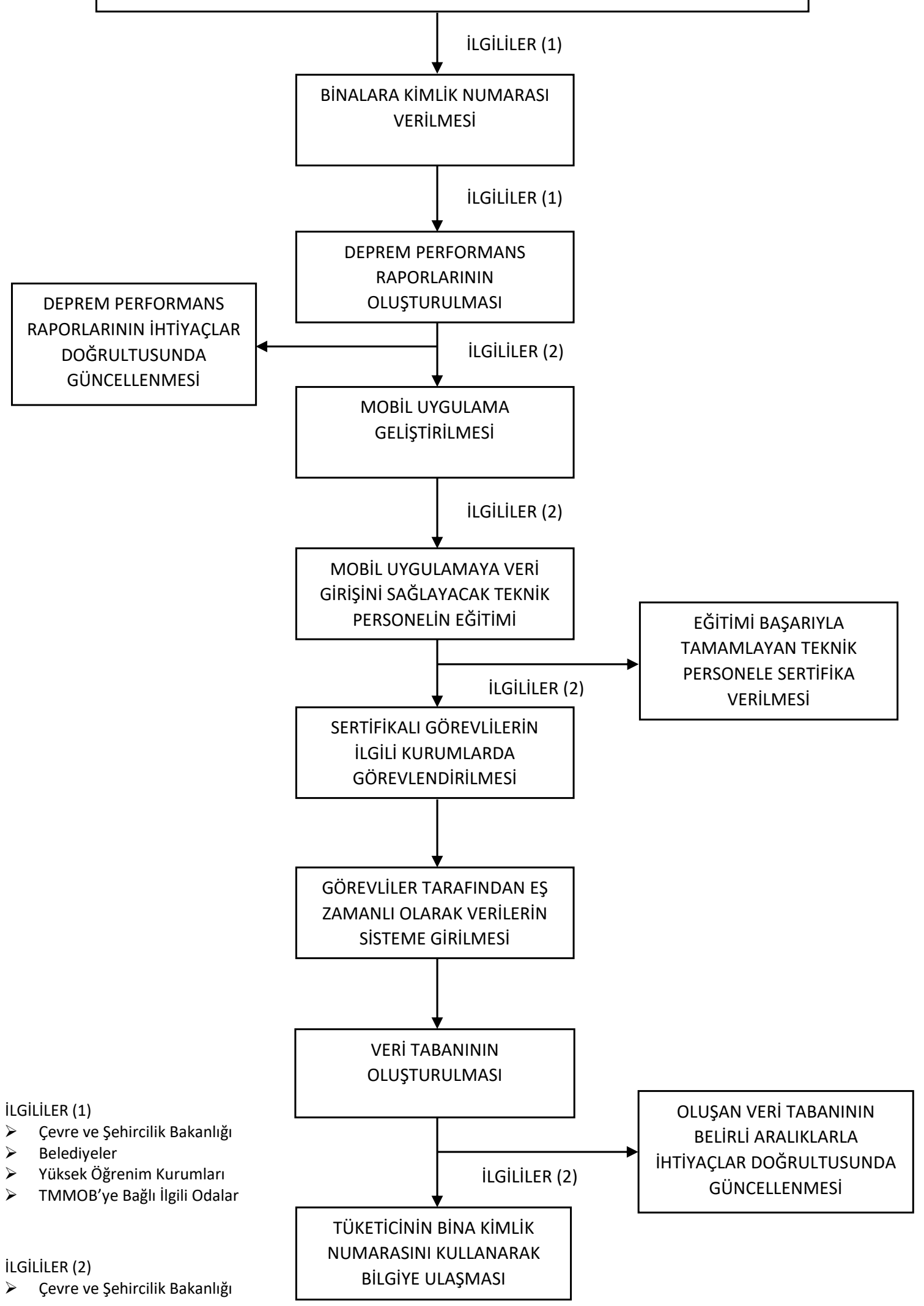

Şekil 7. Konut Özelinde Teknik Bilgilerin Tüketiciye Ulaştırılma Süreci 
Türkiye'de Deprem Performansına Dayalı Bina Kimlik Bilgilerinin Oluşturulmasına Yönelik Çalışma ve Öneriler

Bina kimlik numaralarının kullanıldığı diğer bir bölge ise ABD'nin New York şehridir. New York'ta bina ve adres bilgilerinin tutulduğu GeoSupport adı verilen bir sistem mevcuttur. Bu sistemde her bir parsel için Borough - Block - Lot (BBL) adı verilen 10 haneli numara tanımlanmıştır. BBL numarasında birden fazla binanın tanımlı olması sebebiyle adres karışıklığının önüne geçmek için her bir bina için Building Identification Numbers (BINs) adı verilen 7 haneli bina kimlik numarası kullanılmaktadır. Bina kimlik numarasının ilk hanesi ilçelere verilen tek haneli numaraları temsil etmektedir. Örneğin, Manhattan ilçesi için bina kimlik numaraları 1 ile başlamaktadır. Kalan 6 hane ise sistem tarafından atanmaktadır (Department of New York City Planning, 2017). Bina şayet yıkılırsa binaya tanımlı olan kimlik numarası değiștirilmekte ve yeni bir kimlik numarası ataması yapılmaktadır. Bina kimlik numarası ile binanın adresi, özellikleri, bulunduğu bölgenin erozyon ve sel gibi tehlikelerden etkilenip etkilenmeyeceğine ait detay bilgi, imar belgeleri, bina ile ilgili teknik bilgi ve diğer belgelere ulaşılabilmektedir (NYC Department of Buildings, 2021).

ABD’nin bir diğer şehri olan Atlanta'da Building Identification Number (BIN) adı verilen 6 haneli numaralandırma sistemi kullanılmaktadır (Atlanta Building Efficiency, 2021). Yapılan incelemeye göre numaralandırma için özel bir çalışma mevcut olmayıp numaralar sıralı ve özgün olarak atanmaktadır. Bina kimlik numarası ile binanın alanı, ismi, adresi ve enerji verimliliği ile ilgili bilgilere ulaşılabilmektedir.

Ayrıca ABD'nin Washington DC ve Oregon eyaletine bağlı Portland şehirlerinde bina kimlik numarası uygulaması ile ilgili araştırma yapılmıştır. Bu kapsamda bu iki bölgede bina kimlik numaralarının kullanıldığı görülmüş fakat numaraların nasıl oluşturduklarına dair herhangi bir veriye ulaşılamamıştır. Washington şehrinde adres ve Square Suffix Lot (SSL) adı verilen bina kimlik numaralarının tutulduğu coğrafi bilgi sistemi kullanıldığı belirlenmiștir. SSL’ler 8 haneli rakamlardan oluşmaktadır (Washinghton DC Real Property Finder, 2021). Bina kimlik numaralarının kullanım amacının adres karışıklığının önüne geçmek ve bina bilgilerine erişimi kolaylaştırmak olduğu görülmüştür. Fakat bu özet bilginin dişında kimlik numaralarının oluşumuna yönelik ayrıntılı bir bilgiye ulaşılamamıştır. Portland şehrinde ise bina kimlik numaraları harf ve rakamları içeren 14 hane ve 3 bölümden oluşmaktadır. Building Finder Tool adı verilen platform ile binaların geometrilerine ve kimlik numaralarına erişim sağlanabilmektedir (Portland Building Finder, 2021). Portland'da kullanılan bina kimlik numaraları ile enerji verimliliği ve bina bilgilerine erişimin kolaylaştırılması hedeflenmiştir. Fakat Portland'da da bina kimlik numarasının detaylı olarak nasıl oluşturulduğuna dair herhangi bir çalışmaya ulaşılamamıştır. Aşağıdaki tabloda bu bölümde incelenen bölgelere ait bina kimlik numaralarının örnekleri yer almaktadır (Tablo 2).

Tablo 2. Yurtdışında Kullanılan Bina Kimlik Numaralarına ait Örnekler

\begin{tabular}{|c|c|}
\hline Bölge/Ülke & Bina Kimlik Numarası Örneği \\
\hline Hollanda & 0307100000367968 \\
\hline New York, ABD & 1015219 \\
\hline Atlanta, ABD & 572927 \\
\hline Washington DC, ABD & 100500801 \\
\hline Portland, ABD & 1S2E01AA-1300-B1 \\
\hline
\end{tabular}




\section{SONUÇ VE ÖNERILER}

Deprem kavramının Türkiye için ne denli önemli olduğu yukarıdaki başlıklarda da açıklandığı üzere tüm toplum tarafından bilinmesi gereken bir gerçektir. Depremin yıkıcı tahribatından kaçınabilmek için deprem yönetmelikleri doğrultusunda projeler üretmek, kaliteli mühendislik uygulamaları yapmak ve yapı denetimlerle saha kontrolünü sağlamak yerine getirilmesi gereken zaruri bir şarttır. Buna ek olarak deprem ve etkilerinden kaçınabilmek amacı ile tüketici ya da kullanıcı deprem konusunda bilgilendirilerek mutlaka bilinçli hale getirilmelidir. Bu makalede öncelikli olarak bilinçli tüketici kitlesinin oluşumu hedeflenmiş ve deprem konusunda halkın nasıl bilinçlendirileceğine yönelik önerilere yer verilmiştir. Çalışmadaki asıl amaç ise bilinçlenen tüketicinin sahibi olduğu ya da kiralayacağı binaların depreme dayanıklılık durumu ile teknik özellikleri hakkında anlaşılır bilgiye erişimini sağlamak olmuştur. Bu noktada bilgiyi doğrudan tüketiciye sunmak amacıyla binalar için bina kimlik çalışması önerisi getirilmiştir. Bina kimlik çalışması kapsamında uzmanlar ve yetkililer tarafından hazırlanacak olan deprem performansı değerlendirme raporlarına ait bilgiler verilmiş ve bu raporların tüketiciye tapu belgesi ile birlikte teslim edilmesi gerekliliğine değinilmiştir. Ayrıca binaların depreme dayanıklılık performanslarının tüketiciler tarafından anlaşılabilir olmasını sağlamak amacı ile harf sistemi önerisi de getirilmiştir. Harf sisteminin nasıl tesis edileceğine yönelik bilgiler bina kimlik çalışması başlığı altında açıklanmıştır. Binalar için hazırlanacak olan deprem performans raporları sürecinde bazı temel değişikliklere de gidilmesi gerektiği ifade edilmiş; bu kapsamda binalar için 19 haneden oluşan kimlik numarası önerisine ait bilgilere yer verilmiştir. Bina kimlik numaraları ile birlikte ilgili bina hakkında yapısal, teknik ve diğer tüm bilgilere en hızlı şekilde erişim sağlanarak daha sağlıklı işleyen bir bina envanterinin hazırlanması hedeflenmiştir. Bu kapsamda tüketicinin bina kimlik numaralarını kullanarak ihtiyaç duyduğu bilgiye ulaşabilmesini sağlamak amacı ile mobil uygulama çalışmasına ait bilgiler verilmiştir. Makalede açıklanan hedef bina envanteri, riskli yapılar ve bu mevcut yapıların performanslarının belirlenmesi, bilinçli tüketici oluşumu ve bina kimlik numaraları arasındaki ilişkiler ile planlanan hedef süreler Şekil 8'de şematik olarak ifade edilmiştir. 
Türkiye'de Deprem Performansına Dayalı Bina Kimlik Bilgilerinin Oluşturulmasına Yönelik Çalışma ve Öneriler

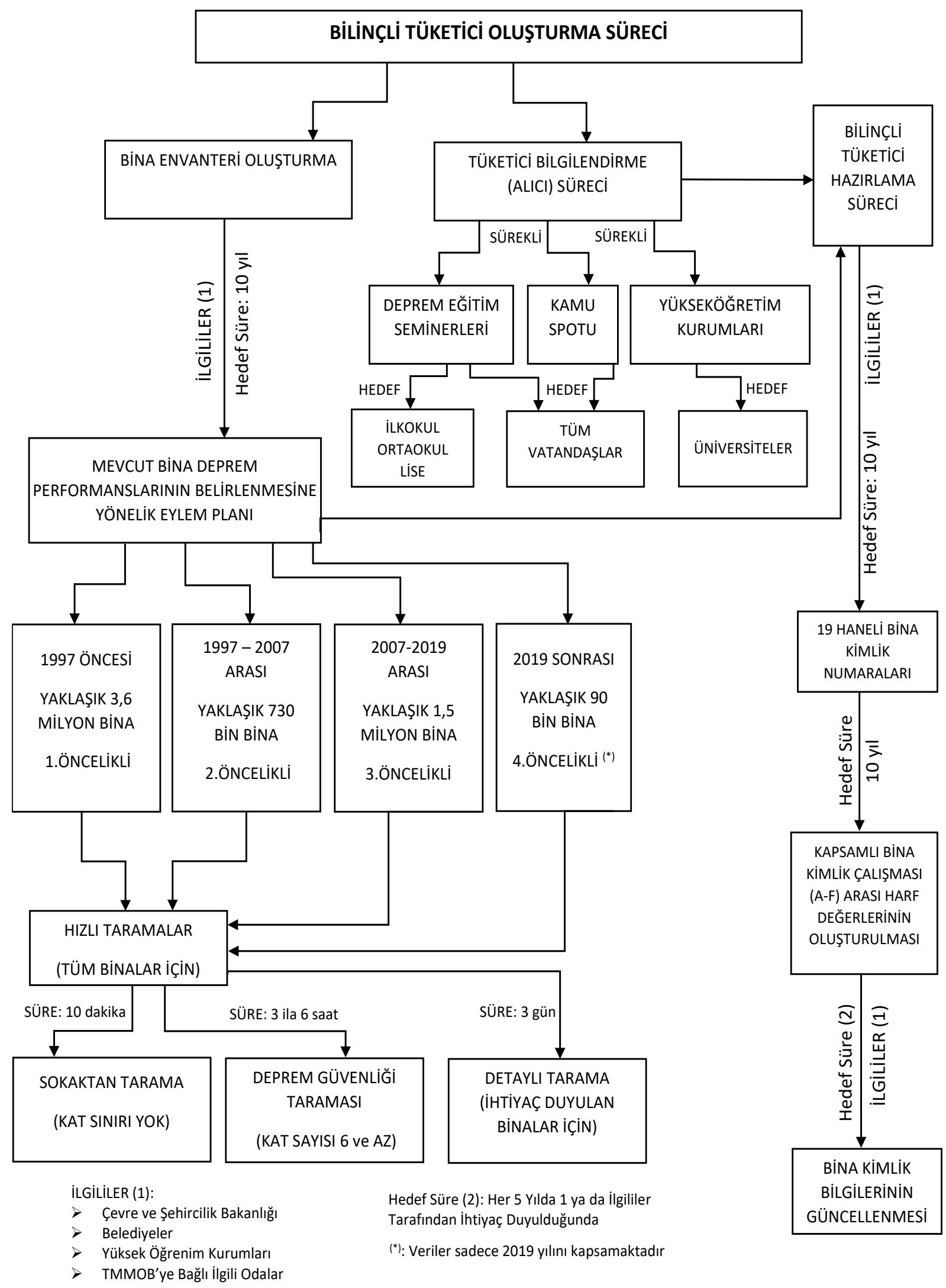

Şekil 8. Bilinçli Tüketici Oluşturma Süreci 


\section{KAYNAKLAR}

AFAD. (2018). Türkiye Deprem Tehlike Haritası. https://deprem.afad.gov.tr/deprem-tehlike-haritasi (Son erişim tarihi: 01.11 .2020 )

AFAD. (2019, Ağustos 25). Afet ve Acil Durum Yönetimi Başkanlığı. https://www.afad.gov.tr/depremnedir\#: :text=Yer\%20kabu\%C4\%9Fu\%20i\%C3\%A7indeki\%20k\%C4\%B1r\%C4\%B1lmalar\%20nedeniyl e,sarsma\%20olay\%C4\%B1na\%20\%E2\%80\%9CDEPREM\%E2\%80\%9D\%20denir. (Son erişim tarihi: 12.08.2020)

AFAD. (2020). https://deprem.afad.gov.tr/depremkatalogu (Son erişim tarihi: 09.09.2020)

AFAD. (2020, Şubat 20). Elazığ Depremi Sonrası Yapılan Tüm Yardımlar. https://www.afad.gov.tr/elazigdepremi-sonrasi-yapilan-yardimlar-merkezicerik (Son erişim tarihi: 12.10.2020)

Afyon Kocatepe Üniversitesi Deprem Uygulama ve Araştırma Merkezi. (2020). Depremlerin Oluşumu ve Türleri. https://deprem.aku.edu.tr/depremlerin-olusumu-ve-turleri/ (Son erişim tarihi: 03.10.2020)

Apaydın, F. (2020). Bina Girişlerine Bilgi Künyesi Koyarak Bina Tüketicilerinin Binalara Yönelik Tutumlarını Etkileme, Siirt Üniversitesi Sosyal Bilimler Enstitüsü Dergisi, 15, s. 70-93.

Atlanta Building Efficiency. (2021). https://atlantabuildingefficiency.com/compliance/ (Son erişim tarihi: 15.01.2021)

BAG. (2018). https://www.kadaster.nl/zakelijk/registraties/basisregistraties/bag (Son erişim tarihi: 15.01.2021)

Boduroğlu, M. H., Özdemir Çağlayan, P. (2007). Mevcut Yapıların Değerlendirilmesinde Bir Tarama Yöntemi. 6. Ulusal Deprem Mühendisliği Konferansı, s. 157-166. İstanbul. http://www.imo.org.tr/resimler/ekutuphane/pdf/2668.pdf

DASK. (2018). Doğal Afet Kurumu Zorunlu Deprem Sigortası Faaliyet Raporu. https://www.dask.gov.tr/content/pdf/2018_dask_faaliyet_raporu.pdf (Son erişim tarihi: 03.04.2020)

Demirtürk, D., Tunç, G. (2021). İnşaat Mühendisliği Eğitimi ve Türkiye'de İnşaat Sektörünün Lisans Eğitimine Bakış Açısı, Engineering Sciences (NWSAENS), 16(1):15-38, DOI: 10.12739/NWSA.2021.16.1.1A0466.

Department of New York City Planning. (2017). GeoSupport System User Programming Guide. https://www1.nyc.gov/assets/planning/download/pdf/data-maps/open-data/upg.pdf?r=16b (Son erişim tarihi: 15.01.2021)

Ercan, A. (2013). Yapı İnceleme Yöntemleri, Birsen Yayınevi, İstanbul.

Gökçe, H. (2011, Ekim 31). 11 ylldır bina sayımı yapılmadı. https://www.dunya.com/gundem/11-yildirbina-sayimi-yapilmadi-haberi-157696 (Son erişim tarihi: 15.10.2020)

Gürgün, A. , Koç, K. , Atabay, Ş. (2022). Yapı Bilgi Modellemesi Kullanımının Sürdürülebilir Yeșil Bina Projeleri Üzerine Etkileri. Teknik Dergi, 33 (3), DOI: 10.18400/tekderg.715574.

Güvel, E. A. (2008, Şubat 20-22). Türkiye'de Depremin İkincil (Makroekonomik) Etkilerinin Ekonometrik Analizi. Sosyal Çalışma Dergisi, s. 1-15. http://debis.deu.edu.tr/userweb//iibf_kongre/dosyalar/guvel.pdf

İşçi, P. (2008). Deprem Nedir ve Nasıl Korunuruz ?. Journal of Yasar University, 3 (9), s. 959-983. https://dergipark.org.tr/tr/download/article-file/179169

İșmen, A. (2006). Depremin Psikolojik Etkileri: Daha Az Zarar Görmek Mümkün Mü?. Frrat Üniversitesi Sosyal Bilimler Dergisi, 16 (1), s. 349-362. http://web.firat.edu.tr/sosyalbil/dergi/arsiv/cilt16/sayi1/349362.pdf 
Türkiye'de Deprem Performansına Dayalı Bina Kimlik Bilgilerinin Oluşturulmasına Yönelik Çalışma ve Öneriler

Karka, O., Akyılmaz, F. (2009). Afetlerde Psikolojik İlkyardım. İstanbul İl Afet ve Acil Durum Müdürlüğü. İstanbul.

ilkyardim.pdf http://www.guvenliyasam.org/wp-content/uploads/2016/02/Afetlerde-Psikolojik-

Kılınç, T., Şahin, İ. (2016, Temmuz). Türkiye'de 1980-2014 Yılları Arasında Görülen Depremlerin Ekonomik Etkileri. Siirt Üniversitesi İktisadi ve İdari Bilimler Fakültesi İktisadi Yenilik Dergisi. https://dergipark.org.tr/en/download/article-file/210453.

Maden Tetkik ve Arama Genel Müdürlüğü. (2020a). Maden Tetkik ve Arama Genel Müdürlüğü Web sitesi: https://www.mta.gov.tr/v3.0/bilgi-merkezi/deprem_potansiyeli (Son erişim tarihi: 02.01.2020)

Maden Tetkik ve Arama Genel Müdürlüğü. (2020b). http://www.mta.gov.tr/v3.0/bilgi-merkezi/dirifay (Son erişim tarihi: 02.01.2020)

Maliyeti 5 Milyar TL. (2020, Mayıs 30). Net Haber: https://malatyanethaber.com.tr/maliyeti-5-milyartl/22683/ (Son erişim tarihi: 08.10.2020)

Mertol, H. C., Tunç, G., Akıș, T. (2020, Ocak 24). Elazığ-Sivrice Deprem Raporu. Atılım Üniversitesi, Ankara.

NYC Department of Buildings. (2021). Building Information Search. http://a810bisweb.nyc.gov/bisweb/bispi00.jsp (Son erişim tarihi: 15.01.2021)

Özkul, M. H., Uçar, S., Şaşmaz, Ç., Yanpınar, H. (2011). Türkiye'de Hazır Betonda Kalite Denetimleri. Türkiye Hazır Beton Birliği-Hazır Beton Dergisi, s. 77-84.

Özmen, B., Can, H. (2010). Türkiye'nin Deprem Gerçeği Paneli. Ankara: Gazi Üniversitesi. http://webftp.gazi.edu.tr/deprem/turkiyenin_deprem_gercegi_paneli_kitabi.pdf

Pampal, S., Özmen, B. (2007). Türkiye'nin deprem gerçeği: Deprem Bölgeleri Haritaları ve Deprem Yönetmeliklerinin Tarihsel Gelişimi Gerçeği. Ankara.

Pekşen, E., Aşcı, M. (2015). Jeofizikte Hasarsız Yapı İnceleme Çalıştay Kitapçı̆̆ı. Jeofizik Mühendisleri Odası, Kocaeli Şubesi.

Portland Building Finder. (2021). https://www.portlandmaps.com/bps/buildingfinder/ (Son erişim tarihi: 15.01.2021)

Sabah, L., Bayraktar, H. (2020). Düzce Merkez ve İlçelerinin Deprem Senaryolarına Göre Karşılaștırmalı Olarak İncelenmesi. Düzce Üniversitesi Bilim ve Teknoloji Dergisi, 8(2), s. 1695-1705. https://doi.org/10.29130/dubited.574013

Sucuoğlu, H. (2007). Kentsel Yapı Stoklarında Deprem Risklerinin Sokaktan Tarama Yöntemi İle Belirlenmesi. Altıncı Ulusal Deprem Mühendisliği Konferansı, s. 267-284. İstanbul. http://www.imo.org.tr/resimler/ekutuphane/pdf/2675.pdf

Süer Toybıyık, S. (2017). Coğrafi Tabanlı Bina Envanterinin Oluşturulması. Ankara. https://webdosya.csb.gov.tr/db/cbs/icerikler/05.06.2017_tez_s-bel_suer_toybiyik-20180925134345.pdf

T.C. Bayındırlık Bakanlığı, Afet İşleri Genel Müdürlüğü. (1996, Ağustos). https://www.afad.gov.tr/ (Son erişim tarihi: 15.01.2021)

T.C. Çevre ve Şehircilik Bakanlığı. (2012, Temmuz). Türkiye Kent Bilgi Sistemleri Standartlarının Belirlenmesi Projesi: KBS Veri Temaları Tanımlayıcı Dokümanı: https://csb.gov.tr/uygulamalar

T.C. Çevre ve Şehircilik Bakanlığı. (2012, Aralık 17). Afet Riski Altındaki Alanların Dönüştürülmesi Hakkında Kanunun Uygulama Yönetmeliği: https://altyapi.csb.gov.tr/6306-sayili-kanun-uygulama-yonetmeligiyeni-duyuru-522 
T.C. Çevre ve Şehircilik Bakanlığı. (2019, Eylül 12). Kentsel Dönüşüm Eylem Planı Açıklandı: https://csb.gov.tr/kentsel-donusum-eylem-plani-aciklandi-bakanlik-faaliyetleri-28602

T.C. Resmi Gazete. (1961, Eylül 2). https://www.resmigazete.gov.tr/arsiv/10896.pdf

T.C. Resmi Gazete. (1968, Ocak 16). Afet Bölgelerinde Yaplacak Yönetmelik Hakkında: https://www.resmigazete.gov.tr/arsiv/12801.pdf

T.C. Resmi Gazete. (1975, Haziran 9). Afet Bölgelerinde Yapılacak Yapılar Hakkında Yönetmelik: https://www.resmigazete.gov.tr/arsiv/15260.pdf

T.C. Resmi Gazete. (1997, Eylül 2). Afet Bölgelerinde Yapılacak Yapılar Hakkında Yönetmelik: https://www.resmigazete.gov.tr/arsiv/23098_1.pdf

T.C. Resmi Gazete. (2007, Mart 6). Deprem Bölgelerinde Yapılacak Binalar Hakkında Yönetmelik: https://www.resmigazete.gov.tr/eskiler/2007/03/20070306-3.htm

T.C. Resmi Gazete. (2018, Mart 18). Türkiye Bina Deprem Yönetmeliği: https://www.resmigazete.gov.tr/eskiler/2018/03/20180318M1-2.htm

Tabak, S. (2020, Ocak 29). 8 Yılda 515 bin bina dönüștü. 8 Yılda 515 bin bina dönüștü: https://www.sabah.com.tr/ekonomi/2020/01/29/8-yilda-515-bin-bina-donustu (Son erişim tarihi: 15.09.2020)

TMMOB. (2012). Türkiye'de Deprem Gerçeği ve TMMOB Makine Mühendisleri Odası'nın Önerileri Oda Raporu. Ankara.

Tokgöz, H., Bayraktar, H. (2019). Deprem tehlikesine maruz yerleşimler için "Yerel Deprem Puanı (YDP)” yönteminin geliștirilmesi. Politeknik Dergisi, 22(2): s. 269-276.

Tunç, G. (2015). Depreme Dayanıklı Bina, Bilinçli Tüketici ve Güven Kavramları Üzerine İnceleme ve Öneriler. Türkiye Deprem Mühendisliği ve Sismoloji Konferansı, İzmir. https://www.researchgate.net/publication/299838713_Depreme_Dayanikli_Bina_Bilincli_Tuketici_ve_Gu ven_Kavramlari_Uzerine_Inceleme_ve_Oneriler

Tunç, G. (2020). Depreme Dayanıklı Yapı Tasarımında Teknolojik Gelişmeler. Yapı Dergisi, Sayı 459, s. 62 67. https://www.researchgate.net/publication/344202487_Depreme_Dayanikli_Yapi_Tasariminda_Teknoloji k_Gelismeler_Technological_Advances_in_Earthquake_Resistant_Structural_Design

Tunç, T. E., Tunç, G. (2021). Transferring Technical Knowledge to Turkey: American Engineers, Scientific Experts, and the Erzincan Earthquake of 1939, Notes and Records, DOI:10.1098/rsnr.2020.0054.

TÜİK. (2020). https://biruni.tuik.gov.tr/medas/?kn=135\&locale=tr (Son erişim tarihi: 07.09.2020)

Türkiye'nin yarısı Kütahya merkezli depremle sallandı. (2011, Mayıs 20). Milliyet: https://www.milliyet.com.tr/gundem/turkiyenin-yarisi-kutahya-merkezli-depremle-sallandi-1392397 (Son erişim tarihi: 11.09.2020)

Uğurlu, A. (2013, Haziran 14). Depremde Beton ve Davranışı. Türkiye Mühendislik Haberleri. 58/2013-2, s. 57-63.

Uzun, Ö., Balyemez, S. (2020). İstanbul ve Antakya Şehirlerinde Deprem Risk Azaltma Çalışmaları Üzerine Karşılaştırmalı Bir Değerlendirme. İstanbul Aydın Üniversitesi Dergisi, 12(3), s. 229-250. https://dergipark.org.tr/tr/pub/iaud/issue/56118/771885

Washington DC Real Property $\quad$ Finder. https://dcgis.maps.arcgis.com/apps/webappviewer/index.html?id=3ca919beca684ea7bd7d1ced0dbbf63 6/ (Son erişim tarihi: 15.01.2021) 